\title{
Papers
}

Matthias M. Tischler

\section{Translation-Based Chronicles, Twelfth to Thirteenth Centuries. New Sources for the Arabo-Latin Translation Movement in the Iberian Peninsula ${ }^{\star}$}

\begin{abstract}
Within the well-known panorama of the Arabo-Latin translation movement in the Iberian Peninsula from the twelfth century onwards, the transfer of Arabic biographical and historiographical texts into Latin writing is clearly understudied. Earlier research has focussed on the Arabo-Latin transfer of philosophical, scientific and religious texts without taking into account the role of biohistorical material within the history of cultural exchange and entanglements between Muslims and Christians. And even more recent research on Latin historiographical writing has still not been fully aware of these processes of Arabo-Latin transfer and transformation that also exist. The article analyzes three outstanding Arabo-Latin chronicles from the twelfth and thirteenth centuries, the Chronica gothorum Pseudo-Isidoriana, the Chronica latina regum Castellae and Rodrigo Jiménez de Rada's Historia Arabum, thus examining different types of written and oral transfer of Arabo-Latin historical knowledge and finally introducing the notion of 'frontier historiography' to describe these translation-based chronicles.
\end{abstract}

Keywords: Iberian Peninsula, Arabo-Latin translation movement, Chronica gothorum Pseudo-Isidoriana, Chronica latina regum Castellae, Rodrigo Jiménez de Rada, Historia Arabum

DOI 10.1515/jtms-2014-0005

Matthias M. Tischler, Institut d'Estudis Medievals, Universitat Autònoma de Barcelona, Bellaterra, matthias.tischler@uab.cat 


\section{State-of-the-Art}

Some years ago, when I was preparing a paper on Iberian Arabo-Latin translations of Muslim texts from the twelfth to fifteenth centuries, I met for the first time with the phenomenon that I would nowadays call 'translation-based chronicles'. In this specific form of more or less universal Latin historiography from the frontier societies of the Iberian Peninsula, we do not only find traces of written and oral Arabic traditions, but also information about the religious traditions and writings of Islam, its founder Muhammad and other leaders of the Maghrebian and Andalusian denominations of this religious movement. When I further asserted that even the Estoria de España, from the Court of Alphonse the Wise, had used a Castilian translation of the famous Legend of Muhammad's nightly journey to heaven, ${ }^{1}$ my research began to look for older Iberian historiographical texts that contain a high degree of traces of Arabo-Latin processes of religious transfer and transformation, and I have become since then more and more aware of their spatial and mental contexts of production. Yet, what can we learn about the translation movement in the Iberian Peninsula when we consider not only the Arabo-Latin transfer of philosophical and scientific texts but also the neighbouring transfer of Arabic historiographical and biographical traditions? For a long time, we have known about the very early integration of Arabic, that is, Muzarabic, traditions on Muhammad into the Latin polemical literature from the eighth/ninth centuries onwards, ${ }^{2}$ or about the Arabic translation, or better, redaction of the late antique universal chronicle of Orosius in the tenth century. ${ }^{3}$ What I want to discuss in this paper is the position of three largely neglected Arabo-Latin chronicles from the twelfth to thirteenth centuries within the scenario of the Iberian translation movement: the Chronica gothorum Pseudo-Isidoriana, ${ }^{4}$ the Chronica latina regum Castellae ${ }^{5}$ and the Historia Arabum by Rodrigo Jiménez de Rada. ${ }^{6}$ Until now these three historiographical entities have

1 TISCHLER 2011a, p. 131 n. 28; TISCHLER 2011b, p. 339 n. 28.

2 TISCHLER 2008; TISCHLER 2012a; TISCHLER 2012b. In her latest overview on Muzarabic historiographical traditions CARDELLE DE HARTMANN 2011 even stops before the Chronica gothorum Pseudo-Isidoriana (p. 41).

3 LEVI DELLA VIDA 1951; LEVI DELla VidA 1954; DAIBER 1986; PENELAS 2001a; PENELAS 2001b; PENELAS 2001c; Christys 2002, p. 135-157; Penelas 2002; PEnelas 2009; DAIBER 2011; SAHNER 2013 (who has overlooked Hans Daiber's latest publication mentioned here). See also n. 15.

4 Chronica gothorum Pseudo-Isidoriana.

5 Chronica latina regum Castellae.

6 RODERICUS XIMENIUS DE RADA Historia Arabum. These three chronicles are only spuriously mentioned by LINEHAN 1993, p. 320, p. 325 n. 41 and p. 326 n. 45 (Chronica latina regum Castellae); p. 
been analyzed in a very traditional manner by tracing their written 'sources' and by discovering their authors - as the first and second chronicles are anonymous works and the third one, authored by the archbishop of Toledo Rodrigo Jiménez de Rada, has only found its rightful place in the concept of contemporary historiographical writing of Castile-Leon some years ago. ${ }^{7}$ Ongoing research has since focused on further traditional topics represented in these chronicles, such as the role of the Iberian military orders or the use of power and violence in the so-called Reconquista. $^{8}$

The main objectives of my paper are 1) to make us more aware of the important role of the translated written and oral traditions, used in these (and other) chronicles, within the general context of the Iberian translation movement of the twelfth and thirteenth centuries; 2) to sensitize us to the methodological problems we are confronted with, when regarding the interrelationship of written and oral traditions within the field of Arabo-Latin translations; 3) to reflect orality as one of the still underestimated and therefore understudied causes for the variety of similar but not identical traditions produced by processes of Arabo-Latin transfer; and 4) to suggest that these particular forms of writing history at the linguistic, cultural and religious edge of Iberian transcultural societies should be qualified as 'frontier historiography'. To answer these four enquiries, we should first of all investigate the dates, locations, authors and purposes of the three chronicles.

392 n. 23 (Historia Arabum). The Chronica gothorum Pseudo-Isidoriana and the Arabo-Latin transfer within Iberian historiography seem to have been forgotten or neglected in this otherwise invaluable monograph. MITRE FERNÁNDEZ 1994, p. 411 sq. shortly mentions the Chronica latina regum Castellae and the Historia Arabum without discussing the Arabo-Latin transfer within these two historiographical works. GIL FERNÁNDEZ 1995, p. 20 sq., $83-87$ and 105 sq. mentions the Chronica gothorum Pseudo-Isidoriana, the Chronica latina regum Castellae and the Historia Arabum.

7 MASER 2006; MASER 2012.

8 JOSSERAND 2003; JEAN-MARIE 2005. 


\section{Three Examples for 'Translation-Based Chronicles'}

\subsection{The Chronica gothorum Pseudo-Isidoriana}

The Chronica gothorum Pseudo-Isidorian ${ }^{9}$ has been called by its first editor Theodor Mommsen Historia Pseudoisidoriana. ${ }^{10}$ In concert with the observation, made by Giorgio Levi della Vida, that the reference to the Maghreb in c. 7 is not possible before the end of the eleventh century, ${ }^{11}$ previous research has opted for a Muzarabic Latin translation of an Arabic model, ${ }^{12}$ realized in Toledo after the city's reconquest by king Alfonso VI. ${ }^{13}$ In the meantime, scholarly opinion has favoured the argument for a skilled composition of original Latin and translated

\footnotetext{
9 Chronica gothorum Pseudo-Isidoriana: DíAZ y DíaZ 1970, p. 320; DE CARlos VIllamaRín 1996, p. 241-256; GonZÁLEZ MuÑOZ 2000. The only known copy of this work is the South-Western French codex Paris, Bibliothèque nationale de France, Ms. lat. 6113, fol. 27r-49r, second half of the twelfth century, probably from the Narbonnais: TISCHLER 2001, p. 73 sq. The model seems to have been written in Visigothic minuscule, as we can learn from characteristic misspellings: BENITO VIDAL 1961, p. 248-250; GAUTIER-DALCHÉ 1984, p. 17 sq. and 20. For the further textual contexts of this chronicle in this manuscript: ibid., p. 14-16; GONZÁLEZ MUÑOZ 2000, p. 16-18; CHRISTYS 2010. 10 MOMMSEN 1894, p. 377.

11 "ad derbesllandas marroquinas et affricanas partes", Chronica gothorum Pseudo-Isidoriana 2000, p. 146 1. 71 sq.: LEVI DELLA VIDA 1943, p. 186 n. 27; LEVI DELLA VIDA 1954, p. 289 n. 4.

12 MenÉndez Pidal 1924, p. 16 with n. 1; SÁnCHeZ AlboRnoz 1934, p. 238 with n. 21; SÁnCHeZ ALBORNOZ 1942b, p. 34 n. 112. MENÉNDEZ PIDAL 1954, p. 6 and 13 sq. has made the case for a redaction of the Arabic version in Toledo in the first half of the tenth century.

13 SÁNCHEZ AlbORNOZ 1942b, p. 30, p. 34 n. 112, p. 35, 38 sq., 41 sq. and 44-46 has argued for a work in Toledo in the years before the town's reconquest in 1085. SÁNCHEZ ALBORNOZ 1946, p. 74, 89-98, 100, p. 101 n. 90, p. 102 and p. 111 n. 119 has then pleaded for the work of a Murcian Muzarabic cleric in Toledo of the late eleventh century. The latter's opinion is followed with certain reservations by CATALÁN MENÉNDEZ-PIDAL 1975, p. XXXII with n. 25 sq. BENITO VIDAL 1961, p. 252 has then assumed an author working in Sevilla, whereas PASCUAL MARTíneZ 1972, p. 49-51 and 56-60 has favoured again a Murcian author of the late eleventh century in Toledo. DíAZ Y DíAZ 1979, p. 85 with n. 51 has even postponed the redaction of the text until the first half of the thirteenth century in the Toledan milieu of Rodrigo Jiménez de Rada, but this cannot be possible because of the earlier date of the transmitting manuscript: as n. 9. All these suggestions for dating and locating the Latin redaction have not gained general acceptance.
} 
Latino-Arabic and original Arabic ${ }^{14}$ traditions $^{15}$ from the first half of the twelfth century, ${ }^{16}$ made in the geographical and cultural context of Catalonia or Aragón. ${ }^{17}$ The chronicle outlines - not without a certain influence of Isidore of Seville's model - the history of Spain from the beginnings to the Arabic conquest as the history of a geographically and climatically outstanding mega-region of several superseding peoples and cultures. In its final section, the chronicle is based on Arabic traditions telling us about the legend of the kidnapping of Julian's daughter by Witiza (instead of Rodrigo) ${ }^{18}$ and thus offering a different explanation for the reasons of the Iberian Peninsula's Berber invasion, ${ }^{19}$ which the

14 That means a Latin retro-conversion of an Arabic compilation of originally Latin texts, among them especially the world chronicle of Paulus Orosius: as n. 15.

15 Among the Arabic main traditions have emerged the Ahbār Mulūk al-Andalus ('History of the Kings of al-Andalus') by the Cordoban Muslim historian ar-Rāzī (889-955), transmitted only in an incomplete Castilian version of a Portuguese translation, and the Arabic translation of Paulus Orosius' Historia adversus paganos, presumably made by the Cordoban Christian historian Ḥaf̦ ibn Albar al-Qūṭi (fl. 889) in collaboration with the learned Muslim courtier Qāsim ibn Așbağ: SÁnCHeZ Albornoz 1934, p. 240-249 and 257; SÁnCheZ Albornoz 1942a, p. 34 n. 34 sq., p. 168 n. 64 and p. 190-193; SÁNCHEZ ALBORNOZ 1946, p. 76 sq., 83, 89-103 and 105 sq.; LEVI DELLA VIDA 1962, p. 181 sq.; Catalấ MenéndeZ-Pidal 1975, p. XXXII-LXIX; GonZÁlez MuÑoZ 1990; GonZÁleZ MUÑOZ 2000, p. 12-16, 22-30, 32, 39 sq., 42, 47-49, 64, 66, 73 sq. and 82-91; CHRISTYS 2006.

16 LEVI DELLA VIDA 1943. The period of redaction can be limited because the reference to S. Nicola de Bari (c. 1) before the translation of the saint's relics in 1087 (GAUTIER-DALCHÉ 1984, p. 24), the naming of Santiago de Compostela (c. 8: "Sanctus Iacobus") instead of Iria as the diocese of Braga before December 5, 1095 (BENITo VIDAL 1961, p. 251) and the mention of Saint-Gilles (c. 1) (probably as Mediterranean harbour for the crusaders) are not possible before the twelfth century (GAUTIER-DALCHÉ 1984, p. 24; GONZÁLEZ MUÑOZ 2000, p. 94). Further arguments for dating the redaction into the first half of the twelfth century are the passing mention of the "byzanteus" as coin not before ca. 1100 in Latin texts (GAUTIER-DALCHÉ 1984, p. 24; GONZÁLEZ MUÑOZ 2000, p. 94 sq.) and the quasi no longer existing column of Hercules in Cádiz, which had been destroyed in 1145 (GAUTIER-DALCHÉ 1984, p. 25; GONZÁlEZ MUÑOZ 2000, p. 95) (c. 1: ibid., p. 94 sq.). In the meantime MonTENegro VAlentín/DEL CASTILlo 2004, p. 1060-1062 tend to date the work again to the late eleventh century.

17 The chronicler's standpoint, relating to Aquitania and Narbonne, depends on his point of view (c. 1): "Primus igitur angulus ad orientem se extendit, habens Aquitaniam ad sinistram partem, Narbonam vero ad dexteram iuxta mare Medit`erıraneum, cuilibet ad orientem spectanti, ad occidentem vero aspicienti Narbona est illi e converso ad sinistram, Aquitania ad dexteram", Chronica gothorum Pseudo-Isidoriana 2000, p. 110 1. 10-14: GAUTIER-DALCHÉ 1984, p. 28; GONZÁLEZ MUÑOZ 2000, p. 27.

18 DesWARTE 2000, p. 70-72 and 76.

19 ClAUde 1988; KAMPERS 2008, p. 222-235. 
Arabic historiography had collected from oral traditions. ${ }^{20}$ With regard to this specific Arabo-Latin historiographical background, the Chronica gothorum Pseudo-Isidoriana is a somewhat methodological precursor of the Historia Arabum, written by Rodrigo Jiménez de Rada in the thirteenth century. So we can confirm that at least two Latin chronicles with a Latino-Arabic and Arabic background have come to light in the Iberian context between the twelfth and thirteenth centuries. The phenomenon of 'historiographical translations' is thus another characteristic feature of the era of Arabo-Latin translations between the old region of Septimania, the Ebro valley and Toledo and does not exist only since Rodrigo Jiménez de Rada in the thirteenth century, as one can read even in most recent literature. ${ }^{21}$

With his division of Spain between a Southern part of the Muslims and a Northern part (of the Christians), the author clearly reveals his Christian position, ${ }^{22}$ which explains his very poor knowledge of Islam: Apart from two small references to Muhammad's lifetime, ${ }^{23}$ we only find one short passage from a now lost Liber prophetarum, ${ }^{24}$ which has been used by Aḥmad ar-Rāzī in the tenth century, ${ }^{25}$ referring to Muhammad's alleged journey to the town of Eribon ("Oribe"),

20 SÁNCHeZ AlboRnoz 1934, p. 247 with n. 48; GONZÁlez MuÑOZ 2000, p. 21 and 79-82; ChristyS 2006, p. 359, 361 and 363-369; CHRISTYS 2010, p. 80 and 86. For the further evaluation of this final section see below p. 195.

21 This has been ignored by DREWS 2006, p. 262; MASER 2006, p. 67; MASER 2012, p. 230 sq., because they have not taken into consideration the Chronica gothorum Pseudo-Isidoriana and the Chronica latina regum Castellae.

$22 \S 1$ : "refertur etiam ab illis [sc. "auctoribus"] duas esse Yspanias, superiorem scilicet et inferiorem vel citeriorem et ulteriorem, altera citima Mauris, altera plane ab illis remota”, Chronica gothorum Pseudo-Isidoriana 2000, p. 110 1. 21-23: GAUTIER-DALCHÉ 1984, p. 28. GONZÁLEZ MuÑOZ 2000, p. 28 has assumed here the influence of Isidore of Seville, Etymologiae XIV IV, 30, who, however, does not show any concept of religious spatial structures between Christians and Muslims. The author's opinion on the moral squalidness of the Moorish parts of Spain does not exceed common Christian anti-Muslim polemics: "superior Yspania Gall<i>a Braccata apellatur, ubi tanta est insolentia, tantusque fastus, nec non et arrogancia copiosa”, Chronica gothorum Pseudo-Isidoriana 2000, p. 112 1.1-3: GAUTIER-DALCHÉ 1984, p. 29 sq.

23 § 17: “anno Mahomet XXX annis”, Chronica gothorum Pseudo-Isidoriana 2000, p. 174 1. 15; § 18: “decem annis anno Mahomet”, ibid., p. 178 1. 5: GonZÁLEZ MuÑoZ 2000, p. 20.

24 § 18: "hic [sc. "Gondolus"] direxit legatos ad barbaros et ad gentes Oribe, sicut narrant libri prophetarum”, Chronica gothorum Pseudo-Isidoriana 2000, p. 178 1. 3 sq.: GONZÁLEZ MuÑOZ 2000, p. 73 sq.

25 Crónica del moro Rasis c. 130: "E este [sc. "Gundasulid"] enbio sus cartas a los barbaros ... E yo falle escrito en los libros de los christianos, en aquellos que fablan de los mandados de los rreys, que este enbio su mandado a los de Oriba et a los de Semeden, e luego se le rrindieron et le obedeçieron”, AR-RĀZī Crónica del moro Rasis 1975, p. $270 \S 2$ and 5 (version Ca from Toledo, Biblioteca Capitular, Caj. 26-24). The Arabic original of the chronicle is lost. The Castilian version 
as it is attested by the so-called Pseudo-al-Kindī. ${ }^{26}$ This restricted knowledge of (Latino-)Arabic traditions, and the narration coming to an end only shortly after the Moorish conquest of Visigothic Spain, may indicate an early redaction of the Chronicle. But where in Catalonia or Aragón should we look for the location of this 'historiographical translation'? What seems certain is the fact that the model of the only surviving manuscript of the Latin chronicle has been written in Visigothic scripture and that this codex should consequently have been the manuscript of a Muzarabic author, because in the first half of the twelfth century this scripture was already out of use in Catalonia for a long time and even became outdated in Aragón after the end of the eleventh century. This palaeographical observation goes perfectly well with the alleged provenance of the manuscript from the Narbonnais and with the author's specific interest in the old Visigothic ecclesiastical province of Narbonne and some of its sites, ${ }^{27}$ which would reveal an author with some relationship to that region. ${ }^{28}$ We should therefore conclude that the Chronica gothorum Pseudo-Isidoriana has been written in the Northern or

mentions at its very beginning a Portuguese translation made for king John I of Portugal: "Incipit liber Rasae, historici Dalharab Marrochiorum Miramolini Cordubaeque regis quem ipsius iussu composuit. Versus est in linguam Lusitanam ex Arabica, per me magistrum Machometum Saracenum nobilem architectum. Et scribebat mecum Aegidius Petri, clericus Domini Petri Joannidae Portellensis, patris Domini Joannis Auolini”, ibid., p. 3 § 1-3: ColBERT 1962, p. 122.

26 GIL FERNÁNDEZ 1973, p. XLI. GONZÁLEZ MUÑOZ 2000, p. 79 casts doubts on this interpretation. 27 The author probably translates "al-garb” ('Algarve', i.e. 'the West') into “Allogobrorum montes", because the Allobroges, defeated by the Romans, were resettled in the antique Roman province of "Gallia Narbonensis" (c. 1, Chronica gothorum Pseudo-Isidoriana 2000, p. 110 1. 25): GAUTIER-DALCHÉ 1984, p. 17 and 19; GONZÁLEZ MUÑOZ 2000, p. 18 and 23. The author misunderstands "Scamberia", a geographical name of the Celtiberia, as the name of the Septimanian monastery of "Sanctus Tiberius", currently Saint-Thibéry, only $15 \mathrm{~km}$ away from Béziers (Chronica gothorum Pseudo-Isidoriana 2000, p. 112 1. 29): GAUTIER-DALCHÉ 1984, p. 19 sq.; GONZÁLEZ MuÑOZ 2000, p. 18 and 23. He makes the Emperor Carus destroy his native city Narbonne (Eusebios-Hieronymus, Chronicon: "regnavit Carus cum filiis Carino et Numeriano ann〈os〉. .II. ... Carus Narbonensis cum omni Parthorum regione vastata Cochem et Ctesifontem, nobilissimas hostium urbes, cepisset, super Tigridem castra ponens fulmine ictus interiit”, EUSEBIUS-HIERONYMUS Chronicon 1956, p. 2241.19 - p. 225 l. 1), for whence he has to die, struck by lightning: c. 7: “Carus regnavit II annis. Ipse equitavit contra Narbonam ut eam destrueret, ubi fulmine periit“, Chronica gothorum Pseudo-Isidoriana 2000, p. 136 1. 35 sq.: GonZÁLEZ MuÑoZ 2000, p. 48. Among the six Hispanic church provinces, allegedly founded by the emperor Constantine the Great, the first is just the Gallic one of Narbonne: "Prima metropolis est Narbona capud Galliae Braccate. sub metropolitania eius sunt Biteris, Tolosa, Magalona, Nemausum, Carcassona, Luteba, Albia”, Chronica gothorum Pseudo-Isidoriana 2000, p. 138 1. 11-13: GONZÁLEZ MUÑOZ 2000, p. 53 and 57.

28 For the narrow political and cultural relations between the Narbonnais and Northeastern Spain until the twelfth century: MAGNOU-NORTIER 1974, passim; CHRISTYS 2006, p. 370. 
Northeastern parts of Spain, where Muzarabic traditions were still alive. ${ }^{29}$ Furthermore, the transmission of an excerpt of the so-called Chronicon Anianense in the context of our only surviving manuscript of the Chronica gothorum PseudoIsidoriana may draw our attention to a monastery of the former Benedictine congregation of Aniane, ${ }^{30}$ whose radiance ranged from Septimania to Northeastern Spain with its Catalan centre at Ripoll.

Nevertheless, our chronicle seems to be one of the earliest, if not the earliest, evidence for the restoration of Latin historiography in this area, which could perfectly explain its horizon of narration not reaching further than 719 , due to the lack of suitable younger traditions. This lack of ongoing historiographical evidence has obviously directed the author's interest to Latino-Arabic and Arabic traditions and their translation into Latin. ${ }^{31}$ The exact localization of this 'historiographical translation' will decisively contribute to a more detailed mental map

29 A further indication of a centre with Arabo-Latin traditions is the mistake of transforming the actually Latin-Greek-speaking emperor Hadrian (Eusebios-Hieronymus, Chronicon: "regnavit Hadrianus ann`os〉 .XXI. ... Hadrianus eruditissimus in utraque lingua”, EuSEBIUs-HIERONYMuS Chronicon 1956, p. 197 1. 9 sq. and 21 sq.) into a Latin-Arabic-speaking one: "Helius Adrianus regnavit annis XXI, peritus in arabica ling ‘u〉a et latina”, Chronica gothorum Pseudo-Isidoriana 2000, p. 132 1. 35 sq.: GONZÁLEZ MuÑOZ 2000, p. 47 sq.

30 CHRISTYS 2006, p. 371 erronously speaks about 'Charlemagne's testament', taken from Einhart's Vita Karoli: 'This is the only time that the testament was transmitted without the rest of the Vita Karoli. This version was interpolated with extracts from the Chronicle of Aniane which mentioned Charlemagne's gift of a piece of the True Cross to that abbey. Benedict of Aniane (d. 821) was introduced as one of the witnesses'; CHRISTYs 2010, p. 80: '... an extract from Einhard's Vita Karoli'; ibid., p. 89: '... the extract from Einhard's Vita Karoli ... Here the compiler used the Testament of Charlemagne, almost verbatim, but with two significant interpolations, copied from the so-called Chronicon Anianense. Charlemagne's testament is altered in favour of Aniane. Describing the division of his wealth into three parts, and the division of two of the three parts among the twenty-one metropolitan cities of his kingdom. ... In the 'appendix' to Pseudo-Isidore, part of this apparently inalienable third is now assigned to Aniane. As if to confirm this donation, Benedict's name was added to the list of signatories to the will.' In fact, it is a direct extract from the Chronicon Anianense itself: TISCHLER 2001, p. 73 sq. with n. 119 sq.

31 GAUTIER-DALCHÉ 1984, p. 32: “C’est sans doute que l'auteur considérait, à tort ou à raison, que ce texte arabe avait quelque chose à dire - avait peut-être même plus à dire - sur ce passé, et qu'il éprouvait à son égard un respect extrême. Et par là, cette entreprise originale vient s'inscrire dans un plus vaste ensemble. Si l'on veut bien accepter la datation proposée, on ne peut en effet manquer de la rapprocher du mouvement d'intérêt pour les textes scientifiques en arabe qui se développe au XII ${ }^{\mathrm{e}}$ siècle, et se manifeste par de nombreuses traductions, à Tolède mais aussi en Aragon et en Catalogne. En rejoignant ce courant, la 'Pseudo-Isidoriana' cesse d'être un phénomène absolument isolé: elle participe du même intérêt, de la même fascination qui accorde aux érudits musulmans une supériorité indiscutable. Phénomène marginal cependant: son domaine est l'histoire, et secondairement la géographie, étrangères aux préoccupations 
of the early Arabo-Latin translations, made in the Iberian Peninsula from the eleventh and twelfth centuries onwards. ${ }^{32}$

\subsection{The Chronica latina regum Castellae}

Our second historiographical item is the Chronica latina regum Castellae. ${ }^{33}$ This work is more focused on the regional history of Castile from its beginnings as a small Northern Spanish county until the end of November 1236, when it closes its narration with the epoch-making reconquest of Córdoba in that year. ${ }^{34}$ Conceived as a mirror of princes for the royal court of Castile and its political interests against those pronounced by the kingdom of León with regard to its former leading ('imperial') position in Spain, ${ }^{35}$ this historiographical work has been written in and for a decisive phase of the Reconquista. ${ }^{36}$ Offering a real contemporary history, the Chronica latina regum Castellae reveals in many ways notable knowledge of Islam. But who is its author, ${ }^{37}$ who remarkably enough has correctly inserted into the narration of king Alfonso VI's reign of Castile-León a short biography of Ibn Tūmart, the "mahdī" of the Almohads? ${ }^{38}$ Previous research has

purement scientifiques des traducteurs du XII ${ }^{\mathrm{e}}$ siècle. Mais, comme l'histoire et la géographie parlent des hommes, l'auteur n'a pu empêcher que se révèlent les réactions de l'homme derrière le traducteur."

32 For a positioning of the Catalan monastery of Ripoll in the context of early transcultural translation activities from the tenth century onwards: ALVAR 2010, p. 56 sq.

33 Cirot 1912; Cirot 1912-1913; Сirot 1917-1919; Cirot 1919-1923; Cirot 1920; Сirot 1926-1927; Charlo Brea 1998; O’CALLAGHAN 2002; FernáNDEZ ORdóÑEZ 2002-2003, p. 93, 95 sq., 99, 105-108, 112, 114 sq., 117 sq., 121, 126 sq. and 132 sq.; BAUTISTA 2006; LINEHAN 2006; ArIZALETA 2008a, p. 108 sq., 111-117 and 127-133; REILly 2010; CHARLO BREA 2011. The only medieval manuscript of this chronicle is Madrid, Biblioteca de la Real Academia de la Historia, Ms. 9/450 (olim G-1), fol. $88 \mathrm{v}-122 \mathrm{v}$, a late fifteenth-century copy of the original.

34 FALQUE REY 2001, p. 177-179 with n. 7; FALQUE REY 2006.

35 MARTIN 2006.

36 RODRÍGUEZ LÓPEZ 2004b, p. 156; BAUTISTA 2006.

37 Scholars disagree about the number of authors: CHARLO BREA 1995 has argued for a break after king Alfonso IX's (of León) death in 1230 and the re-start of a second author working on this last section of the chronicle. See also O'CALLAGHAN 2002, p. XXX-XXXVII. HERNÁNDEZ 2003, p. 106 n. 2 has pleaded again for one single author. FERNÁNDEZ ORDÓÑEZ 2006 has favoured a three-step redaction of a single author between 1223 and 1237. Most recently REILLY 2010, p. 143 has argued again for one single author.

38 "C`irca inicium regni Imperatoris predicti surrexit quidam Sarracenus, Aven Tummert nomine, qui veniens de partibus civitatis nobilis et famose scilicet Baldac, ubi longo tempore studuerat, predicavit in regno Marroquitano, quod tunc tenebant Mauri, qui speciali nomine 
claimed several ecclesiastical authors for the history, especially the bishops Dominicus of Plasencia and Baeza ${ }^{39}$ and Johannes of Burgo de Osma, ${ }^{40}$ whereas María Desamparados Cabanes Pecourt has made a case for the archbishop of Toledo, Rodrigo Jiménez de Rada himself. ${ }^{41}$ Another argument for Rodrigo or at least his entourage, not yet recognized by Cabanes Pecourt, could be the knowledge of the Latin translation of Ibn Tümart's Book on the Unity and Uniqueness of God (al-'Akida), the so-called Tractatus (or: Libellus) Habentometi de unione Dei, prepared by the canon Mark of Toledo in summer 1213, and the explicit reference to this booklet in the chronicle. ${ }^{42}$ Furthermore, we certainly know that Rodrigo was a member of the Fourth Lateran Council in $1215,{ }^{43}$ a fact the anonymous author ascribes to himself. ${ }^{44}$

dicebantur Moabite, quos vulgus vocat Almorauedes, et nomen regis eorum Ali. Predicavit igitur specialiter contra superbiam et opressionem Moabitarum, qui gentes sibi subditas crudeliter oprimebant, exactiones inmoderatas facientes frequenter ut liberalitatis sue, imo pocius prodigalitatis vicium, quo laborabant et in quo gloriabantur, possent pro libitu suo exerce〈res. Ascivit autem sibi gentes innumeras, que libenter ipsum sequebantur volentes excutere de cervicibus suis iugum durissime servitutis, concilians sibi, tanquam vir sapiens et discretus licet infidelis, animos hominum promictens eis munus inestimabile libertatis. Inter illos autem qui sequebantur predictum Aven Tummert fuit vir discretus, largus et bellicosus, nomine Abdelmum, cuius ministerio in arduis negociis frequencius utebatur. Pugnavit autem predictus Auen Tummert, et fautores sui, contra regem Moabitarum supradictum et contra gentem et sepe victi ab ipsis Moabitis, tandem ipsos vicerunt et eos de regno expellentes, civitatem famosam, scilicet Marrocos, occupaverunt. Institutus est autem rex in predicta civitate et in regno Moabitarum Abdelmum supradictus per manum Auen Tummert, quasi prophete sui. Nominati sunt autem illi sic qui obtinuerunt regnum predictum Almohades, hoc est Unientes, quia scilicet unum deum se colere fatebantur, quem predicavit Auen Tummert, sicut in libello quodam, quem ipse composuit, manifeste declaratur”, Chronica latina regum Castellae 1984, p. 61.22 - p. 7 1. 22.

39 CiROT 1919-1923, p. 200.

40 LOMAX 1963, p. 207-211. For Johannes of Burgo de Osma furthermore: BALLESTEROS BERETTA 1940-1941; SERRANO 1941; FERNÁNDEZ MARTín 1964; LINEHAN 2003a; LiNEHAN 2003 b.

41 Cabanes PeCourt 1964, p. 11.

42 “... quia scilicet unum deum se colere fatebantur, quem predicavit Auen Tummert, sicut in libello quodam, quem ipse composuit, manifeste declaratur”, Chronica latina regum Castellae 1984, p. 7 1. 20-22. The existence of this translation (MARCUS TOLETANUS Tractatus Habentometi de unione Dei) has been overlooked by O'CALLAGHan 2002, p. 14 n. 6: 'Whatever the book may have been, it does not appear to be extant'. But see GRIFFEL 2005, p. 770 sq. and 774 sq. Another candidate for this knowledge could be Johannes of Burgo de Osma himself, who had been educated in Burgos, where Mauritius, the former initiator of Mark of Toledo's translations of Ibn Tūmart's works, became bishop and was succeeded by Johannes in 1240. Furthermore, Johannes, like Rodrido, could have had access to Mark's translations in the Toledo Cathedral library. 43 TANGL 1922, p. 224; Rivera RECIO 1951, p. 336, 338, 340, 342 sq. and 345; LOMAX 1963, p. 205 sq. 44 "Ex illo tempore Latini obtinuerunt Constantinopolim et ecclesia Constantinopolitana obedit ecclesie Romane, cuius patriarcham, non predictum sed successorem eius, vidi ego in concilio 
With his knowledge of contemporary Islam, the author presents himself in the best light: He knows - no matter of course in his time - the Arabic names for the Almoravids and Almohads, ${ }^{45}$ and he knows about the political and religious dissent and the gradual decline of the Almohads' rulership; ${ }^{46}$ he is able to assess

Lateranense convocato sub Innocencio tercio. Quod concilium celebratum est anno revoluto post mortem gloriosi regis, in quo interfuerunt CCCCXX episcopi et LXXII archiepiscopi et patriarcha Constantinopolitanus et Hierosolymitanus et Aquilki ensis et Grandensis. Abbatum vero et priorum et aliis dignitatibus fulgencium non erat numerus. Hoc autem fuit in festo Omnium Sanctorum et idibus mensis iulii sequentis dominus Innocencius tercius, vir bonus, cuius facta properavit Deus, ingresus est in viam universe carnis”, Chronica latina regum Castellae 1984, p. 46 1. 18-29. But the same holds true for Johannes, who participated in this Council as a member of archbishop Rodrigo's "familia”, as we know about a certain "Iohannes abbas" among the Spanish attendees: RIVERA RECIO 1951, p. 350. Is it possible to prove the stay in Rome for Rodrigo and Johannes respectively, when the author witnesses the ordination of the first Latin patriarch of Constantinople by pope Innocent III in March 1205: "Eligitur in patriarcham quidam Venetus, quem ego vidi consecrari Rome in ecclesia Sancti Petri per manum domini Innocencii III", Chronica latina regum Castellae 1984, p. 46, 1. 15-17? An indication of the author's origin is his pejorative opinion about the Basques, which would be in line with a nobleman of Navarrese-Old Castilian origin born in Puente la Reina (Rodrigo), or a nobleman born in the Old Castilian town of Soria (Johannes): "Nobilis igitur rex Castelle licet, tanquam vir sapiens et discretus, intelligeret quod laborare in acquisitione Vasconie hoc esset litus arare, necessitate quadam compulsus, non poterat desistere ab incepto. Paupertas siquidem terre, inconstancia hominum, in quibus rara fides inveniebatur, terram Vasconie ipsi regi rediderant odiosam, sed amor coniugis, et ne ipsam contristaret, ipsum cepto pertinaciter insistere compellebat. Videns tandem quod non proficeret, Vascones ipsos, tam nobiles quam populos civitatum, absolvit a iuramento et omagio, quo ei tenebantur astricti. Felix dies et regno Castelle semper amabilis, qua gloriosus rex pertinacie cessit et destitit ab incepto! Auri fontem irriguum dessicasset Vasconia et nobilitatem procerum hausisset”, Chronica latina regum Castellae 1984, p. 21 1. 25 - p. 22 1. 9.

45 But the chronicle still equilizes "Moabite" and “Almorauedes": as n. 38.

46 "Tunc vero divisis votis in curia Almohade apud Marrocos, que quidem floruerat multis diebus usque ad tempus illud, electus fuit unus in regem, quem alii, quibus non placebat, post paucos dies interfecerunt. Ex qua causa tanta discordia inter potentes illius terre orta est, quanta sedari non potuit usque modo et durat adhuc, et utique duret in eternum. Sicque factum est ut alii alium in regem nominarent, et quisque pro libitu suo vellet habere dominum, quem sibi sperabat fore propicium. Illa igitur discordia, ultra mare orta, redundavit in Yspaniam, ita quod rex Murcie nominatus fuit in regem Marroquitanum, et Hispalis ei favebat et maior pars terre Sarracenorum citra mare. Rex vero Biacie et qui dominabatur Valencie, frater ipsius, et fauctores ipsorum opposuerunt se predicto regi Murcie, iam nominato regi Marroquitano. Sicque divisio magna facta est inter Mauros ultra mare et citra mare, et iam non regnum, quod nutare constat illud Marroquitanum, sed discidium verius poterat nominari. Ex quo quidem facto quisque vere potest scire quod Daniel propheta dixit: 'quia regnum hominum in manu Dei est et cuicumque voluerit dabit illud.' [Dn 4, 29 and 5, 21] Impletum est illud oraculum Ysaye prophete: 'Ve qui predaris! nonne depredaberis? et qui spernis, nonne sperneris? cum consumaveris, depredationem, depredaberis' [Is 33, 1]”, Chronica latina regum Castellae 1984, p. 64 1. 19 - p. 65 1. 10. 
in this context the significance of Ibn Tūmart, ${ }^{47}$ and he even knows king Ferdinand III's private image of Muhammad and his followers in $1224 .{ }^{48}$ Furthermore, the author reveals his own opinion of the godless Moors of Córdoba, ${ }^{49}$ characterizes in the light of the nearly reconquered capital of the former caliphate the Christians as a people of different religion and language, ${ }^{50}$ and assesses the reconquest of Córdoba as an act of restoration of the former Visigothic rulership after a very long period of captivity, ${ }^{51}$ clearly positioning himself as a supporter of the ideology of Leonese Neogothicism. But this historian also has the idea of a religious act of restoration in mind, for he writes as a bishop who, like many

Furthermore: "Ea vero tempestate surrexit in regno Murcie quidam almogar plebeyus, sicut dicebant, strenuus tum in armis, nomine Abenhut, qui pugnavit contra Murcianos, et eis devictis regem eorum cepit et in vinculis posuit, et civitatem et regnum obtinuit, usus consilio cuiusdam ... Mauri potentis et prudentis, quem postmodum idem Abenhut interfecit. Hodio inexorabili persequebatur Almohades, predicans publice non esse obediendum illis tanquam scismaticis in lege sua, quia non obediunt domino de Baldac, qui est de genere Mahometi. Propter quam causam mezquitas suas dicebat purgandas esse tanquam pollutas Almohadum superstitione. Dicebat eosdem Almohades oppresores populi et violentos exactores, se vero asserebat liberatorem populi de Handalucia. Sic enim vocatur cismarina terra Maurorum, unde et populi Handaluces vocantur, quos quidam credunt Vandalos esse. Handaluces autem, credentes virtutem divinam in eodem operari - quia mos est populo illi levi persuasione nova sequi - recedentes a domino Almohadum secuti sunt Auehut quasi regem et dominum, qui, ut placeret eis et inimicicias capitales firmaret inter Almohades et Handaluces, atrocissime decrassatus est in eosdem Almohades, viros capitando, iugulando, diversis penis interimendo, mulieribus mamillas amputando, puerorum vitam morte miserabili extinguendo", ibid., p. 751.17 - p. 761.8 .

47 "Sic et el Mahedi, qui dicebatur Abdelmun de hazedus, qui Moabitas, dominos suos, ad praedicationem Auen Tummert, philosophi de Baldach, regno privavit contra iusticiam sibique gentes et regna subiecit, cum consummavit ista, per Deum zelotem, qui visitavit peccata parentum 'in filios in terciam et quartam generationem' [Nm 14, 18; Ex 20, 5], privatus est regno in posteris suis in diebus nostris. 'Sit nomen Domini benedictum' [Ps 112, 2]”, ibid., p. 65 1. 11-17.

48 "Porta siquidem aperta est et via manifesta. Pax vobis reddita est in regno nostro; discordia et capitales inimicicie inter Mauros, secte et rixe de novo exhorte. Christus Deus et homo ex parte nostra; ex parte vero Maurorum infidelis et dampnatus apostata Mahometus. Quid ergo restat?”, ibid., p. $621.18-22$.

49 "Mauri Cordubenses, qui nec Deum timent nec hominem reverentur, more solito in necem regis et domini sui, regis scilicet Biacie, conspiraverunt”, ibid., p. 71 1. 7-9: RICHARD 1971, p. 122. 50 “Aspexit Corduba populum alterius religionis et lingue, quem non nutrierat”, Chronica latina regum Castellae 1984, p. 93 1. 25 sq.

51 "Sic igitur per virtutem Domini nostri Iesu Christi Corduba, famosa civitas, nitore quodam peculiari et ubere solo predita, queque tanto tempore captiva tenebatur, scilicet a tempore Roderici, regis gotorum, redita est cultui christiano per laborem et strenuitatem domini nostri regis Ferrandi”, ibid., p. 991.12-16. 
Christian authors before him in the Iberian Peninsula ${ }^{52}$ and in the Near East, ${ }^{53}$ articulates the idea of Christian churches polluted by the Muslims, so that these houses of prayer could only be restored by church dedications and holy messes after their military reconquest. ${ }^{54}$ It seems promising to compare again in detail all

52 The idea of restoring former Christian churches, polluted by the sacrilege of the 'Muhammadan' cult, is already formulated in Peter of Aragón and Navarra's charter of donation for the Cathedral of Huesca, April 5, 1097: "atque ubi dominici corporis et sanguinis celebrata fuerant sacramenta nefanda demonum spurcissimique Mahomat colebantur figmenta ... In qua [sc. "urbe Osca"] ad restaurandum antiqui pontificatus apicem, Petro Aragonensi episcopo omnibus Ispanicarum urbium mezquitam contuli excellentiorem. Quam in honore domini Ihesu Christi Nazareni necnon beatissimi apostolorum principis Petri santeque Marie genitricis Dei et sancti Iohannis babtiste atque evangeliste ... dedicari ecclesia feci”, Diploma Petri I regis Aragoniae et Navarrae, p. 90 1. 6-8 and 15-23, or in Alfonso I of Aragón's charter of donation for the Cathedral of Tarazona, 1122. The mosques of the diocese shall be reconverted into Catholic churches: "Similiter concedimus ei [sc. "Michaeli Tirasonensi episcopo"], ut in omnibus villis ipsius episcopus omnes mezquitas ac omnes hereditates omnium illarum mezquitarum in usum ecclesieque eius vendicent; quatenus eliminata ab eisdem omni spurcitia Satane, et sequaces ipsius Mahometh, Iesus Christus Dominus noster in eis adoretur, glorificetur simul et santificetur, et unde demoniorum cultores sustentari videbantur inde videlicet pauperes Christi ad laudem et gloriam nominis ipsius Domini nostri devote [“devolè” ed.] servientes ac humiliter, in eisdem restauratis et noviter consecratis ecclesiis militantes, pro ut ex Evangelio et apostolico precepto acepimus, dignum est, ut qui altari serviunt, quae de altario [!] sunt participant, et ab his sustententur", Diploma Alfonsi I regis Aragoniae, p. 333 1. 5-15. The anonymous author of the Chronica Adefonsi imperatoris II 66 talks about the purgation of Coria, ca. 1147/1149: "Postquam autem reddita est civitas imperatori, mundata est ab inmunditia barbarice gentis et a contaminatione Mahometis et, destructa omni spurcitia paganorum civitatis illius et templi sui, dedicaverunt ecclesiam in honore sancte Marie semper virginis et omnium sanctorum ...”, Chronica Adefonsi imperatoris 1950, p. 125 1. 1-6; Chronica Adefonsi imperatoris 1990, p. 225 1. 1-5: HARRIS 1997, p. 159 sq. n. 9 and p. $162 \mathrm{n} .26$ (with the erroneous allegation of the destruction of the mosques in Coria). The evidently French author of the Translatio brachii S. Eugenii Toletani episcopi § 29, ca. 1153, expresses the idea of Muslim pollution of the Toledan churches: "templa sanctorum titulis consecrata, pro dolor!, mahometici cultus sacrilegio fedarentur”, Translatio brachii S. Eugenii Toletani episcopi, p. 176 1. 22 - p. 177 1. 1. For the evaluation of this text: HENRIET 2000, p. 70-75. The only manuscript of this valuable text is the lectionary Toledo, Biblioteca Capitular, Ms. 48-10, fol. $98 \mathrm{v}-100 \mathrm{v}$, late thirteenth/early fourteenth century.

53 In the tradition of the crusades to the Holy Land, the debate on religious pollution of Christian holy places is a central theme: COLE 1993; ANGENENDT 2009.

54 E.g. the purgation of Campos de Alcoraz (near Huesca): "In die Ascensionis receptus fuit rex gloriosus in eadem villa cum procesione solempni ab archiepiscopo Toletano, purgata Maurorum spurcicia, recedentibus ipsis de villa; et eadem die archiepiscopus missam celebravit ibidem”, Chronica latina regum Castellae 1984, p. 37 1. 6-9; purgation of the mosque of Capilla (near Badajoz): “Archiepiscopus vero Toletanus et episcopus Palentinus et alii viri religiosi, qui cum episcopis erant, mezquitam maurorum, omni spurcicia mahometice superstitionis per virtutem Domini nostri Iesu Christi et victoriosissime Crucis eius purgatam, dedicaverunt ecclesiam 
these political and religious concepts with the irrefutably authentic historiographical work of Rodrigo Jiménez de Rada. ${ }^{55}$

The author of the Chronica latina regum Castellae had not only had direct access to the royal archives and their written official documents; as a political agent of the royal court he had also collected a lot of detailed information from the Muslim side, which had been made available only as oral Arabic or vernacular, but not as written Latin traditions. Yet, these traces of transcultural orality at the royal court of Toledo are neglected by nearly all recent scholars who have dealt with the chronicle's passages on contemporary Almohadian Islam in al-Andalus and in the Maghreb. ${ }^{56}$ Despite the already recognized alterity of contents and narrations in these sections, the latest scholar has only asserted that we could read here 'borrowed material' or 'inserted material', which had been 'borrowed from another text, presumably not a Muslim one for the narrative style is not that of Muslim historical writing, without taking into consideration the possibility of oral communication about this very detailed information on Andalusian Islam and its specific traditions. ${ }^{57}$ Even if we accept the creation of a written Latin short history of Ibn Tümart and the Almohads in the Cathedral chapter of Toledo, ${ }^{58}$ which Rodrigo himself could have used for his own chapter on the appearance of the Almohads in De rebus Hispaniae VII 10 ("De ortu Almohadum"), ${ }^{59}$ and even if

Domino Iesu Christo, missam et divina officia cum magno gaudio celebrantes”, ibid., p. 72 1. 1622; purgation of the famous central mosque of Córdoba and its transformation into the Cathedral: "Felix per omnes mundi cardines dies illuxit Christianis in felice festo apostolorum Petri et Pauli: annua ipsa solempnitas ipsa die agebatur. Circa versperas cancellarius, scilicet Osomensis episcopus, magister Lupus cum eo, qui vexillum Crucis in turrem predictam primo intromisit, intraverunt in mezquitam et preparantes, que neccesaria erant ad hoc, ut ecclesia fieret de mezquita, expulsa Mahometi superstitione vel spurcicia, sanctificaverunt locum per aspersionem aque cum salibus benedicte, et quod prius erat cubile diaboli facta ecclesia Iesu Christi, vocata nomine Genetricis ipsius gloriose”, ibid., p. 991.28 - p. 100 1. 8. For the concept of religious purity in a transcultural comparative perspective: BURSCHEL/MARX 2011; BLEY e. a. 2014.

55 First comparisons relating to the information on contemporary Islam have been drawn between the Chronica latina regum Castellae and Rodrigo's De rebus Hispaniae by CIROT 1912-1913, passim; GonZÁLEZ GONZÁLEZ 1975, p. 63-66. A comparison of both works concerning their conceptions of royal ideology and policy in Castile-León during the first half of the thirteenth century has been drawn by RODRíGUEZ LÓPEZ 2003; RODRíGUEZ LÓPEZ 2004a (also Lucas of Túy, Chronicon mundi); RODRÍGUEZ LÓPEZ 2004c (also Lucas of Túy, Chronicon mundi); RODRÍGUEZ LóPEZ 2006. 56 ARIZALETA 2006 is the only researcher who has explicitly expounded orality as a source for information on contemporary Islam, but only in one isolated case.

57 REILLY 2010, p. 145 sq.

58 Ibid., p. 146 sq.

59 Ibid., p. 147. 
we may emphasize as well the personal memory of the author, ${ }^{60}$ we should not forget orality as a decisive, but almost neglected source of new information about Islam.

Until now, however, this historiographical Arabo-Castilian-Latin transfer has not been compared systematically with other contemporary written or oral traditions, nor has it been integrated into the general panorama of the Arabo-Latin translation movement in the Iberian Peninsula. With the determination of the author and the place of his historiographical activity, we would locate a further piece of the puzzle of our still patchy map of Iberian Arabo-Latin translations within the understudied interlinguistic system of written and oral communication about religious alterity. Whether it has been Johannes, new chancellor for the kingdoms of León and Castile since 1231, and bishop of Burgo de Osma between 1232 and 1240, or Rodrigo Jiménez de Rada, archbishop of Toledo since 1209 and thus Johannes' own archchancellor in Castile, in both cases we can record another Arabo-Latin translation of the late $1230 \mathrm{~s}^{61}$ for the Spanish metropole of Toledo.

\subsection{Rodrigo Jiménez de Rada, Historia Arabum}

To the same historical and geographical context belongs the Historia Arabum, which the aforementioned archbishop Rodrigo Jiménez de Rada (1209-1247) finished in $1245 .{ }^{62}$ But in comparison with my first two historiographical items, this history is based much more on authentic texts on Islam from the Andalusian environment, as it actually paraphrases the content and the language of the older

60 FERNÁNDEZ ORDÓÑEZ 2006, p. 32-34.

61 The latest recorded event is the sale of Paredes de Nava by Álvar Pérez de Castro, July 24, 1237: FERNÁNDEZ ORDÓÑEZ 2006, p. 11 with n. 25.

62 FerRé 1966a; FerRÉ 1966b; REINHARDT/SANTIAGO Otero 1986, p. 303-306; PiCK 2004, p. 6, 75, 77-79 and 177; MASER 2006; DREWS 2011, p. 46-59. 
Arabic historiography of the Iberian Peninsula, ${ }^{63}$ thus constituting a 'historiographical translation' ${ }^{64}$ Besides known Iberian Latin texts like the Chronica Muzarabica and the Liber apologeticus martyrum of Eulogius of Córdoba, ${ }^{65}$ Rodrigo uses Arabic traditions ${ }^{66}$ for a highly authentic Life of Muhammad which he integrates at the very beginning of his 'History of the Spanish Arabs' (c. 1-6). ${ }^{67}$ The life of the Muslims' prophet is therefore the well reflected external starting point for this history of the Arabs living between the Near Orient, Northern Africa and al-Andalus until the end of the eleventh century. ${ }^{68}$ With the end of the caliphate of Córdoba in 1031 and the invasion of the Almoravids between 1086 and 1091 at least in the eyes of Rodrigo - al-Andalus is losing its specific Hispanic identity; the progress of its history beyond the middle of the twelfth century, when the Almohads finally took over the reign from the Almoravids, therefore plays no further role in Rodrigo's concept of a global 'History of Spain', which I shall present in what follows. From now on, the history of Spain is the history of the Christians alone.

Following Rodrigo, Muhammad withdraws from Mekka to Medina, preparing his war against Byzantium and the conquest of Damascus, where he finally is

63 Former research has pleaded for Aḥmad ar-Rāzī’s Ahbār Mulūk al-Andalus, on the one hand, and for Ibn Hayyān's al-Muqtabis II in a shorter version or selected form, on the other hand: SÁNCHEZ AlBORNOZ 1942a, p. 308-316; FERRÉ 1966a; FERRÉ 1966b; CREGO GÓMEZ 2006. But MASER 2006, p. 140-193 and 359-590; MASER 2012, p. 229-232 has shown that this use of texts is not so clear as we would like to see it, because we do not know whether Rodrigo himself is the actual author of this special history or rather the mastermind behind the whole historiographical project.

64 MASER 2007, p. 256. This type of translation explains the numerous namings and explanations of Muslim rulers, as was already indicated by RICHARD 1971, p. 130.

65 MASER 2006, p. 144-146, 194-196, p. 200 n. 228, p. 202 n. 237, p. 210, 222 sq., 264, 267-272 and 290 sq.; p. 220 n. 18 sq. and p. 291 n. 302. Following D’ALVERNY/VAJDA 1951-1952, p. 118 with n. 1 and p. 261 sq. n. 6 and 1; CUTLER 1965, p. 336 with n. 72 and p. 337 sq. with n. 87, Mark of Toledo was acquainted with the works of Eulogius of Córdoba and his friend Paulus Albarus, so that these texts could have been known to Rodrigo as well. Rodrigo could already have read the Chronica Muzarabica in the Cathedral library of Burgo de Osma, where an early copy was available: MOMMSEN 1894, p. 331; GIL FERNÁNDEZ 1973, p. LIX.

66 Ibn Ishāq's Kitāb sīrat rasūl Allāh in the version of Ibn Hišām, the Qur'ān in its second Latin translation by Mark of Toledo, initiated by Rodrigo, and hadiths: MASER 2006, p. 224-293; MASER 2012, p. 235.

67 RODERICUS XimEniUS DE RADA Historia Arabum 1999, p. 88-96: SERRANO Y SANZ 1931-1932, p. 379 sq. with n. 1; RICHARD 1971, p. 110 sq. and 113-117; GAUTIER-DALCHÉ 1981, p. 48 sq.; SCHWINGES 1998, p. 109; Tolan/JOSSERAND 2000, p. 161-164; TOLAN 2003, p. 251; ECHEVARRÍA ARSUAGA 2005, p. 139 sq.; MASER 2006, p. 213-293; DREWS 2011, p. 51; MASER 2012, p. 233-237.

68 For Rodrigo's knowledge and perception of Islam: FERRERO HERNÁNDEZ 2008; PICK 2011. 
proclaimed king. He is said to have been a disciple of the Jewish astrologer Sergius-Bahira, foretelling him his future role as a prophet. In Mekka, furthermore, Muhammad shall have re-erected the old Christian church, lapsed into ruins, and he shall have told fairy-tales to the Christian communities in Syria, e.g. his nightly journey to heaven, with the purpose to persuade them of his prophetical status. ${ }^{69}$ Right here, Rodrigo integrates a short history of the 'religious sect' of the Muslims, portraying Muhammad as a strong adherent of the contemporary opinion of Islam as being a heresy. ${ }^{70}$ In Rodrigo's eyes, Muhammad's religious movement is rooted both in Catholic and in Jewish faith. ${ }^{71}$ Rodrigo's additional knowledge of Islam already displays his mostly Latinized Arabic vocabulary. ${ }^{72}$ The novel, groundbreaking fact is clearly not a 'global' perspective of the integration of knowledge about Muhammad and his movement, ${ }^{73}$ already existing in earlier chronicles, ${ }^{74}$ but its adoption for a global reflexion of the non-Spanish and non-Christian preconditions of the Iberian history of the thirteenth century.

On closer inspection, the 'History of the Spanish Arabs' is neither the first exclusive Latin history of 'another religion' ${ }^{75}$ nor - despite all mentioned innerIslamic struggles since al-Manșūr's death and the resistance of the Andalusian Muslims against the Almovarids and Almohads - a religious history of the Spanish Arabs since the nemesis of the Umayyad dynasty in the Near East. This Historia Arabum is certainly no Historia Sarracenorum; it rather forms part of an early profane 'national' and political 'History of Spain' under the leadership of Castil-

69 Rodrigo witnesses the discovery of this text "in eius secundo libro" (c. 5). That means that he and his team must have translated a written text. Rodrigo knows two versions of the Mi'rā $\breve{g}$, the one given in the redaction of the Kitāb sīrat rasūl Allāh by Ibn Hišām and the short version in the Qur’ān: "In eius secundo libro repperitur scriptum quod ..." and "ut ipse in libro suo mentitur ... Addidit etiam in hoc libro”, RODERICUS XIMENIUS DE RADA Historia Arabum 1999, p. 92 1. 11 sq., p. 931.15 sq. and 31 sq.: ASín y PALACIOS 1919, p. 314; ASÍN Y PALACIOS 1943, p. 376 sq.; MASER 2006, p. 279 with n. 252 and p. 284.

70 RICHARD 1971, p. 113; SCHWINGES 1998, p. 111 sq.

71 C. 2: “.... unde et ipse postmodum aliqua de fide catholica, aliqua de lege veteri in sue secte subsidium usurpavit”, RoDERICUS XIMENIUS DE RADA Historia Arabum 1999, p. 89 1. 9-11.

72 C. 3: "Tunc precepit ut in turribus ubi consueverant campane pulsari, Sarracenus quispiam proclamaret ... Precepit etiam ut in mense Ramadan ieiunarent Xxx diebus”, ibid., p. 911.12 sq. and 14 sq.; c. 6: “... precepta aliqua proferebat, que sub uno compacta capitulo zohara appelabat; et per tales zoharas distinguitur liber eius qui dicitur Alchoranus, in quo tot ignominiosas zoharas predicavit quod puderet dicere, nedum sequi”, ibid., p. 96 1. 24-27.

73 So DREWS 2011, p. 51.

74 TISCHLER 2008, p. 37-48.

75 So PICK 2005, p. 407 ('the first extant work of history in Latin to treat exclusively the rise and spread of Islam'). 
ian Toledo. The Arabs of this history are no longer the simple object of conventional religious polemics, but a self-contained people that a Latin Christian author places for the first time in the correct historical context of the superseding peoples of the Iberian Peninsula. ${ }^{76}$ This concept of a first 'national history' is an absolute necessity for the new kingdom of Castile-León, reunited in 1230 by king Ferdinand III, since the tremendous territorial expansion of Old Castile to al-Andalus after the reconquest of Córdoba in 1236 has confronted the Christians with the enormous problem of the social and religious integration of the numerous Muslims remaining in their former homeland.$^{77}$ In Rodrigo's own words, "Hispania", because of its many strokes of fates and fragmentations by invaders and foreign rulers, is in need of a new consciousness of unity. ${ }^{78}$ Therefore, his Historia Arabum necessarily forms part of a comprehensive historiographical compilation with the Historia de rebus Hispaniae at its centre, as do the translated biographical and historiographical Arabic texts, which are integrated in both single histories. This integration of Arabic traditions is the intellectual model and precondition for the social and religious integration of the Muslims in the new Christian territories. Rodrigo compiled his comprehensive historiographical work between ca. 1240 and 1246 (the Historia Arabum in 1245); it is his mature late work, written exactly in the years before the reconquest of Seville in 1248 by Ferdinand III, king of Castile-León, when the Christian expansion reached out to the Algarve coast and when the Mendicant missions to the Muslims in Southeastern Spain and Northern Africa was coordinated by the metropolite of Spain - archbishop Rodrigo Jiménez de Rada.

76 DREWS 2006, p. 275-281; DREWS 2011, p. 48.

77 DREWs 2006, p. 265 sq.; DREWs 2011, p. 49.

78 Historia de rebus Hispaniae Prologus: “Cum igitur Hispaniarum successus variorum principum cruentis cladibus iteratus et linguam mutaverit et originem sue gentis pluribus intercepta dominiis sit oblita, iam fere gens et origo incolarum Hispanie ignoratur", RODERICUS XIMENIUS DE RADA Historia de rebus Hispanie, p. 61.49-53. 


\section{An Understudied Methodological Problem. The Interrelationship of Written and Oral Traditions within the Field of Arabo-Latin Translations}

In analyzing the multiple oral, literate and written processes of transfer and transformation of knowledge about Muhammad's life and work between the Muslim and Christian societies, we are considering the crossing of boundaries between different modes of narrations and their cultural patterns, on the one hand, and we are rethinking the well-established model of interdependent perception and interpretation, on the other hand. One fundamental issue of this paper is the analysis of the processes of crossing and creating boundaries within the transcultural/religious space of 'passages' of oral, literate and written representations of Muhammad's life and work, ${ }^{80}$ which have been constituted between the transmitting and receiving Muslim and Christian sides. These representations may therefore be called 'textual events' ${ }^{81}$ Whilst considering the multifaceted medieval conception of 'text', ${ }^{82}$ we have to assess the relationship between biographical and historiographical writing, stating that each form of representation may occur within the other and that different textual conceptualizations did exist. ${ }^{83}$ However, until now, this crossing of biographical and historiographical writings has not been thoroughly studied, particularly as it was Christian hagiography (and historiography) in context alone, which has been considered from an almost intracultural perspective. ${ }^{84}$ Furthermore, we see fluid boundaries between Lives and Legends, and both forms of biographical writing are entitled to historical

79 The following chapter is an enlarged and revised version of TISCHLER 2013.

80 For the difference between literacy ('Verschriftung') and writing ('Verschriftlichung'): OESTERREICHER 1993.

81 SPONSLER 2002 describes 'the shifting process of appropriation', but this is unilateral and monolinear thinking. BURKE 2000 prefers the bilateral term 'cultural exchange'. I suggest 'passage(s)' (following Walter Benjamin) in BoRgOLTE/TISCHLER 2012a, p. 12-15. The papers in FEuCHTER e. a. 2011 underline the necessity of being sensitized to cultural, social and ideological conditions and implications for and in the representations of cultural transfer.

82 KUCHENBUCH/KLEINE 2006.

83 LIFSHITZ 1994 wrongly argues that separating historiography and hagiography is not possible until the twelfth century. This statement should be regarded as unfounded since both modes of inquiring into the past belong to different areas of handling knowledge (education, liturgy ...). 84 BAUER/HERBERS 2000. 
truth and authenticity. Legendary writing within historiography is an item of research as well, yet again almost from an intracultural point of view. ${ }^{85}$

When scrutinizing the aforementioned 'passages', we consider a whole bundle of medial and linguistic, as well as cultural and religious, processes of transfer and transformation. Curiously enough, exchanges between oral, literate and written traditions on Muhammad's life and work have not been discussed in the relevant literature on medieval memory, ${ }^{86}$ even though the massive transition from oral to literate representations and oral traditions, especially in historiographical work from our research period, has been studied. ${ }^{87}$ Thus, it is expected that behind the variance of recurring components of narratives on Muhammad's life and afterlife there would be no implicit proof of intertextuality, but instead clear hints of foreign and proper orality, which does not mention explicitly the bearers of private information and public opinion.

This short evaluation of the state-of-the-art could well be extended to the studies that have been conducted on our three selected Arabo-Latin chronicles. A clear deficit of methodological reflection on transcultural processes of transfer and transformation can be observed, which is consequently followed by a lamentable lack of historical insight into the creation of new Christian narratives of Islam.

Medieval writing about the new cultural and religious phenomenon, considered very early, ${ }^{88}$ and which involved changing the conceptual framework of linguistic and cultural dispositions of the historians, was highly influenced by the authors' social, linguistic and cultural proximity to the object of perception and interpretation. Therefore, the written work on cultural and religious alterity depends on the ability to cross at least two barriers: on the one hand, the linguistic and cultural barrier of missing proficiency in Arabic, Syriac and Greek, and on the other hand, the mental and intellectual barrier of ignorance and indifference towards the potential of a challenge to one's own position by the religious other. ${ }^{89}$ Nevertheless, in this model of cultural transfer between relatively distant semi-

85 BIETENHOLZ 1994; GOETZ 1999, p. 147.

86 YATES 1966; STOCK 1983; GOODY e. a. 1986; GOODY 1987; ZUMTHOR 1987; CARRUTHERS 1990; ColeMAN 1992; GEARY 1994; RICHTER 1994a; RICHTER 1994b; RICHTER 1995; WENZEL 1995. Even the Freiburg Sonderforschungsbereich (i.e. Collaborative Research Centre) 321 'Übergänge und Spannungsfelder zwischen Mündlichkeit und Schriftlichkeit’ (1985-1996) did not offer a research project on this central topic.

87 VOLLRATH 1991 (intracultural perspective).

88 Especially in the Byzantine world: TISCHLER 2012c.

89 TISCHLER 2009. 
otic systems, the central role of orality or oral communication has not been sufficiently determined. Orality in the processes of transfer and translation in its proper sense would mean that we do not consider processes of translation between four eyes ${ }^{90}$ or between two hands, ${ }^{91}$ but processes of convers(at)ion between two mouths and brains. The traces of these processes of oral communication are hidden in the specific forms of narration in our texts.

Different forms of orchestration of oral and written texts may be distinguished here. In the Chronica gothorum Pseudo-Isidoriana, our first model, only the final section on the conquest of Spain ${ }^{92}$ is written as a sequence of dialogues: firstly, at the royal Visigothic court between Witiza ("Geticus") and an unnamed general ("dux") on the (dishonest) capture of Julian's daughter, then between Julian himself and his squire on this fraudulent act, and eventually between Julian and Taāriq ibn Ziyād on the possible conquest of Spain to avenge this act (c. 19); ${ }^{93}$ subsequently, after Witiza's death we are presented with a dialogue between his sons and Tāariq ibn Ziyād on how to ensure the victory over king Rodrigo (c. 20); ${ }^{94}$ and finally, there is a conversation between Theudemir and Taăriq ibn Ziyād and between the latter and Julian on the final phase of conquest (c. 21). ${ }^{95}$ This is clearly the Christian-Arabic re-enactment of oral traditions filtered out of the Arabic models of anecdotic and dialogic narrations, the so-called "ahbār"tradition. ${ }^{96}$

90 ROMANO 1971.

91 D'ALVERNY 1989.

92 For the (earliest) Arabic traditions on the conquest of al-Andalus from 711 onwards and for their often contradictory and lamentably scarce contents: Collins 1989, p. 4 sq.; MoLINA MARTíneZ 1998; MANZANo MORENo 1999; Christys 2002, p. 6; THOMAS 2008, p. 101-117 (with some methodological weaknesses in his argumentation). For a general assessement of the Arabic, Latin and Romance traditions of the following events: KRAPPE 1923; MENÉNDEZ PIDAL 1924.

93 Chronica gothorum Pseudo-Isidoriana 2000, p. 182-184.

94 Ibid., p. 186. Parallel Arabic tradition: AR-RĀZī Crónica del moro Rasis 1971, p. 132 sq. (Ms. U): MANZANO MORENO 1999, p. 413 n. 74.

95 Chronica gothorum Pseudo-Isidoriana 2000, p. 188-190. Parallel Arabic tradition: AR-RĀZī Crónica del moro Rasis 1971, p. 134-142 (Ms. U). However, Theudemir's surrender of Murcia and Orihuela to Ṭāriq ibn Ziyād in April 713 and its anachronistic positioning between Rodrigo's fall (July 711) and the occupation of Toledo by Țāriq (October 711) is paralleled in the Ahbār Mağmū'a: Ahbār Mağmū'a, p. 12-15 (Arabic text) and 26-28 (Spanish version).

96 After the monograph SÁNCHEZ ALBORNOZ 1944, there has been at least a spurious debate on the multiple oral character of many traditions of the historiographical compilation Ahbār Mağmū'a: CHALMETA GENDRón 1973, p. 30 and 54 sq.; MOLINA MARTíneZ 1989, p. 520 sq., 533 and 535; OLIVER PÉREZ 2000-2001, p. 517 sq., 529 sq., 536-538, 540-548, 551 and 553; OLIVER PÉREZ 2001, p. 81, 87-89, 96-98 and 103-105; OLIVER PÉREZ 2002, p. 132, 139 and 143. 
Another mode of orality in written texts is signalled by keywords or 'rubrics' introducing explicit oral narratives on contemporary Islam in al-Andalus. In this way, the opinions and news of individuals or whole groups of persons are referenced. We can assess this manner of written orality in the Chronica latina regum Castellae, which has not yet been studied from this perspective - and curiously enough - not even in its latest critical edition. ${ }^{97}$ Rubrics like "dicebatur", "sicut dicebant”, “dicebat”, “asserebat”, "sicut asseritur a multis”, “ista didicimus fama referente” or "creditur” refer to detailed information on Abd al-Mu'min's (Ibn Tūmart's successor) defeat of the Almoravids, ${ }^{98}$ on Ibn Hud's (alias al-Mutawakkil's) rebellion in Murcia and his victory over the Almohads, ${ }^{99}$ on Muhammad I ibn Nașr's cruel punishment of the brother of the țā'ifa king of Baeza ${ }^{100}$ and on Abū Yaḥyā at-Tinmalālī's death, full of grief of despair about his son's decapitation, ${ }^{101}$ whereas "vocatur" or "vocantur" display specific Arabo-Latin vocabulary. ${ }^{102}$ In his report of the reconquest of Úbeda (1233), the author even mentions explicitly Moorish prisoners of that town as his informants, ${ }^{103}$ and he also relies on (Christian) eye witnesses for his description of the marvellous Muslim palace of Córdoba. ${ }^{104}$

Another clearly understudied aspect of the Arabo-Latin historiography is the persistence of the Arabic tradition; namely, that already in the Arabic models the oral "ahbār"-tradition is an essential reason for the sophisticated techniques of

97 Charlo BREA 1997.

98 As n. 47.

99 As n. 46.

100 “Quod ut oblatum est ei [sc. "regi Marroquitano"], sicut asseritur a multis, virga, quam tenebat in manu, percussit, verbis contumeliosis usus in dedecus ipsius [sc. "regis Biacie"] et tocius parentele eius. Cui cum respondisset aspere quidam frater regis Biacie, percussus est ab ipso rege Marroquitano cum gladio, et sic orta seditione mulıti ex utraque parte cede mutua occubuerunt. Ista didicimus fama referente”, Chronica latina regum Castellae 1984, p. 71 1. 14-20.

101 "Capta fuit igitur predicta civitas [sc. "Maiorica"] ultima die mensis decembris, anno ab incarnatione domini MCCXxIX. Rex Maiorice post paucos dies mortuus est, decapitato filio eius, quem tenerrime diligebat; unde pre dolore nimio creditur expirasse”, ibid., p. 79 1. 10-14.

102 As n. 46.

103 "Sicut referebant aliqui de Mauris ipsis, qui tunc in eadem villa [sc. "Ubeda"] capti fuerunt", Chronica latina regum Castellae 1984, p. 351.7 sq.

104 "Missa igitur sollempniter celebrata per Osomensem episcopum et benedictione super populum data, dominus rex intravit in palacium nobilissimum, quod reges Maurorum sibi preparaverant, de quo tot et tanta dicuntur ab his qui viderunt, quod a non videntibus incredibilia iudicantur”, ibid., p. 100 1. 15-19. 
compilation in Islamic historiography ${ }^{105}$ and that this very manner of writing history is one of the intrinsic reasons for the variance of narrations of the same historical events. Nevertheless, to our dismay, the memory of the authors of AraboLatin processes of transfer was intricately involved in an intensive communicative situation between Arabic-vernacular orality and Latin literacy, which implies that the multilingual communication situation is a tricky filter for creating Latin memory. Orality is therefore not only one of the still underestimated reasons for the variety of similar but not identical traditions produced by processes of AraboLatin transfer; it is also responsible for the reduction of this variety of traditions lost in Arabo-Latin translation. It is exactly this third mode of a more hidden orality that can be found in the Historia Arabum, in which Rodrigo's translation team shows this very sophisticated scholastic way of homogenizing the varying Arabic traditions about the same historical events. ${ }^{106}$ The central challenge in our ongoing research is thus the detection and comprehension of these oral processes, since written records of the vernacular step between the Arabic and Latin versions have only been preserved from the thirteenth century onwards. ${ }^{107}$

With regard to the historiographical background on the Muslim side, we are now able to understand why, for instance, Wibert of Nogent explicitly mentions orality as the source for his first knowledge of Muhammad and Islam, creating a narrative plot of his most reliable referees. ${ }^{108}$ And we can also better assess the variance of the seemingly analogous but never identical legendary narratives of Muhammad, which apparently emerged in the context of Arabo-vernacular-Latin communication situations during their encounters in Northern Spain and which

105 Rosenthal 1968, p. 66-71; Chalmeta Gendrón 1972, p. 360 sq. and 368; Chalmeta GeNDRÓN 1973; LEDER 1992; NOTH/CONRAD 1994, p. 62; DONNER 1998, p. 6, 14 sq., 255 sq., 260, 262-266 and 279-281; ROBINSON 2003, p. 15-19; HIRSCHLER 2006, p. 86.

106 This complex of orality behind Arabo-Latin (historiographical) translations and its transforming effects have not been considered by MASER 2006, p. 143 sq., 154 sq., 171 sq., 174, 180, 188 sq. and 192; MASER 2012, although he has detected some traces of orally transmitted knowledge of Muhammad: MASER 2006, p. 236, 292 sq. and 431 (“alii dicunt”).

107 MENÉNDEZ PIDAL 1951, p. 365 sq.; D’ALVERNY 1989, p. 199-201.

108 I 3: "Plebeia opinio est quendam fuisse qui, si bene eum exprimo, Mathometus nuncupetur ... Cuius mores vitamque cum nusquam scripta didicerim, quae a quibusdam disertioribus dici vulgo audierim nulli debet esse mirum si dicere velim”, GUITBERTUS DE NOVIGENTO Dei gesta per Francos, p. 94 1. 244 sq. and 253-255: MUNRo 1931, p. 333; SOUTHERn 1962, p. 31; DANiEL 1975, p. 236; BISCHOFF 1984b, p. 108; FLORI 1992, p. 253; ROTTER 1994, p. 82 sq. with n. 81 sq.; LUCHITSKAJA 1999, p. 724. Guibert's oral tradition stems from the Christian-Arabic context of the Eastern Mediterranean because of some striking similiarities with Embricho of Mayence's Vita Mahumeti (ROTTER 1994, p. 82 n. 82), whose narration comes from the Near East: HoTz 2002, p. 29-35, 86 sq. and 96. 
then were inserted into several French chronicles from the late eleventh century onwards, as for instance in Hugh of Flavigny or Hugh of Fleury. ${ }^{109}$

\title{
4 'Frontier Historiography'
}

We may briefly summarize our observations. a. From the geographical perspective, we can identify a gradual shift of the translation activity to the South of the Iberian Peninsula, following on the one hand the Reconquista from Northern and Northeastern Spain to the centre in Toledo and confirming on the other hand the already known map of the Iberian Arabo-Latin translation areas of other spheres of knowledge. b. From the social and religious standpoint, we see perhaps a change of the translation activity from the monastic to the canonical milieus, that is, from monasteries to cathedral chapters. c. With regard to the typology of texts, we clearly observe a typical Iberian mixed genre between translation and historiography, the 'translation-based Arabo-Latin chronicle', which perfectly represents what we call nowadays 'entangled history'. d. Finally, in terms of the notion of frontier, we may be encouraged to characterize this specific form of historiographical writing at the edge of languages, cultures and religions of the Iberian frontier societies as 'frontier historiography'. Especially its geographical and communicative vicinity to the Arabic side seems to plead for this new notion, coined in view of the already introduced term 'frontier hagiography' ${ }^{110}$

\section{Abbreviations}

\author{
BHL Bibliotheca Hagiographica Latina \\ CChr.CM Corpus Christianorum. Continuatio Mediaevalis \\ CChr.SL Corpus Christianorum. Series Latina \\ PL Patrologia Latina
}

109 Hugo FlaviniaCensis Chronicon, p. 323 1. 32-41: KeDAR 1984, p. 86 sq. and 211; ROTTER 1994, p. 87 sq. with n. 113; ROTTER 2004, p. 332 with n. 239; TISCHLER 2008, p. 39. HUGO FLORIACENSIS Historia ecclesiastica a. 1109; HUGO FLORIACENSIS Historia ecclesiastica a. 1110: D’ALVERNY 1965, p. 599 with n. 46; DANIEL 1975, p. 235-237; KEDAR 1984, p. 87 and 208-210; DANIEL 1993, p. 31; NOTH 1993, p. 379; ROTTER 2004, p. 333 sq.; TISCHLER, 2008, p. 38 with n. 31.

110 Whereas this notion generally pertains to texts with a certain geographical distance to the Muslim side: VIÑAYo GoNZÁLEZ 1984, p. 74-77; GARCÍA DE LA BORBOLLA 2000; GONZÁLEZ JIMÉNEZ 2003, p. 158-163; GARCía DE LA BORBOLLA 2006. 


\section{Bibliography}

\section{Texts}

Ahbār Mağmū'a

Ahbār Mağmū'a fi-iftitāh al-Andalus ..., ed./trad. Emilio LAfUente y AlCÁnTARA: Ajbar Machmuâ. Colleción de tradiciones. Crónica anónima del siglo xI, dada á luz por primera vez (Colección de obras arábigas de historia y geografía [1]), Madrid 1867 [repr. Madrid 1984], 1-165 (Arabic text) and 15-142 (Spanish version).

Chronica Adefonsi imperatoris

Chronica Adefonsi imperatoris, ed. LUIS SÁNCHEZ BeLdA: Crónica Adefonsi imperatoris. Edición y estudio (CSIC. Escuela de Estudios Medievales. Textos 14), Madrid 1950, 3-206; ed. Antonio MaYa [SÁnCHEZ]: Chronica Hispana saeculi XII 1: Chronica Adefonsi Imperatoris (CChr.CM 71), Turnhout 1990, 149-248.

Chronica gothorum Pseudo-Isidoriana

Chronica gothorum Pseudo-Isidoriana, ed. THEOdOR MOMmSEN: Chronica minora saec. IV. v. VI. VII 2 (MGH Auctores antiquissimi 11), Berlin 1894, 378-388; ed. ANTONIO BENITO VIDAL: Crónica Seudo Isidoriana. Edición e índices (Textos medievales 5), València 1961, 11-53; ed. FeRnANDo GonZÁlez MuÑoz: La chronica gothorum pseudo-isidoriana (ms. Paris BN 6113). Edición crítica, traducción y estudio (Biblioteca Filológica 6), A Coruña 2000, 110-190.

Chronica latina regum Castellae

Chronica latina regum Castellae, ed. CIROT 1912-1913; ed. MARÍA DeSAMPARAdos CABANES PECOURT: Crónica latina de los reyes de Castilla. Edición crítica e índices (Textos medievales 11), València 1964, 15-124 [Zaragoza $\left.{ }^{3} 1985,15-92\right]$; ed. LuIS CHARLo BREA: Crónica Latina de los reyes de Castilla. Introducción, texto crítico, traducción, notas e índices, Cádiz 1984 [1999], 1-102; ed. LuIS Charlo BreA: Chronica Hispana saeculi XIII (CChr.CM 73), Turnhout 1997, 35-118.

Diploma Alfonsi I regis Aragoniae

Diploma Alfonsi I regis Aragoniae [1122], ed. VICENTE DE LA FUENTE: España sagrada ... 49: La Santa Iglesia de Tarazona en sus estados antiguo y moderno, Madrid 1865, 332 sq. $\mathrm{n}^{\circ} \mathrm{XI}$.

Diploma Petri I regis Aragoniae et Navarrae

Diploma Petri I regis Aragoniae et Navarrae [1097 IV 5], ed. ANTONIO DURÁN GUDIOL: Colección diplomática de la Catedral de Huesca 1 (CSIC. Fuentes para la historia del Pirineo 5. Escuela de estudios medievales. Textos 34. Publicaciones de la Sección de Zaragoza 10), Zaragoza 1965, 89-91 nº 64.

EUSEBIUS-HIERONYMUS Chronicon

Eusebius-Hieronymus: Chronicon, ed. John Knight Fotheringham: Eusebii Pamphili chronici canones, latine vertit, audauxit, ad sua tempora produxit S. Eusebius Hieronymus, London 1923, 1-332; ed. Rudolf Helm: Eusebius, Werke 7: Die Chronik des Hieronymus. Hieronymi Chronicon (Die griechischen christlichen Schriftsteller der ersten drei Jahrhunderte 47), Berlin (Ost) ${ }^{2} 1956,1-253$.

GUITBERTUS DE NOVIGENTO Dei gesta per Francos

GUitbertus ABbAs de Novigento: Dei gesta per Francos, ed. Robert BurChard CONSTANTIJn HuYGENS: Guitberti abbatis Sanctae Mariae Novigenti Historia quae inscribitur Dei gesta per Francos quinque accedentibus appendicibus (CChr.CM 127 A), Turnhout 1996, 77-352. 


\section{Hugo FlaVINIACENSIS Chronicon}

Hugo abBas FlaviniaCensis: Chronicon Virdunense seu Flaviniacense, ed. GeORg HeInRICH PERTZ: MGH Scriptores 8, Hannover 1848, 285-502.

HUGO FLORIACENSIS Historia ecclesiastica a. 1109

Hugo monachus Floriacensis: Historia ecclesiastica, ed. Benjamin Zeev Kedar: Crusade and mission. European approaches toward the Muslims, Princeton (NJ.) 1984, 208a-210a (partial edition; $1^{\text {st }}$ redaction in four books from 1109).

HUGO FLORIACENSIS Historia ecclesiastica a. 1110

HUGO MONACHUS FLORIACENSIS: Historia ecclesiastica, ed. GEORG WAITZ: MGH Scriptores 9, Hannover 1851, 354-364 (partial edition; repr. PL 163, 829-854); ed. Benjamin Zeev KedAR: Crusade and mission. European approaches toward the Muslims, Princeton (NJ.) 1984, 208b$210 \mathrm{~b}$ (partial edition; $2^{\text {nd }}$ redaction in six books from 1110 ).

Marcus Toletanus Tractatus Habentometi de unione Dei

Marcus Canonicus Toletanus: Tractatus Habentometi de unione Dei, ed. D'Alverny/VajDA 1951-1952, 269-279.

AR-RāZī Crónica del moro Rasis

AḤMAD AR-RĀZī: Crónica del moro Rasis, ed. Diego CATALÁn [MENÉndeZ-PIDAL]/MaRía SoledAd de ANDRÉS: Edición crítica del texto español de la Crónica de 1344 que ordenó el Conde de Barcelos don Pedro Alfonso (Fuentes cronísticas de la historia de España 2), Madrid 1971, 1208; ed. Diego Catalán [Menéndez-Pidal]/María Soledad de Andrés: Crónica del moro Rasis. Versión del Ajbār mulūk al-Andalus de Aḥmad ibn Muḥammad ibn Mūsà al-Rāzī, 889-955. Romanzada para el rey Don Dionís de Portugal hacia 1300 por Mahomad, alarife, y Gil Pérez, clérigo de Don Perianes Porçel (Fuentes cronísticas de la historia de España 3), Madrid 1975, 3-284.

RODERICUS XIMENIUS DE RADA Historia Arabum

Rodericus XIMEnIUS de RAdA: Historia Arabum, ed. José LozAno SánCHEZ: Rodrigo Jiménez de Rada, Historia arabum. Introducción, edición crítica, notas e indices (Publicaciones de la Universidad de Sevilla. Serie Filosofía y letras 21), Sevilla 1974 [²1993], 3-71; ed. JUAN FERNÁNDEZ VALVERDE: Roderici Ximenii de Rada Historiae minores. Dialogus libri vitae (CChr.CM 72 C), Turnhout 1999, 87-149.

RODERICUS XIMENIUS DE RADA Historia de rebus Hispanie

ROderICUS XIMENIUS DE RADA: Historia de rebus Hispanie sive Historia gothica, ed. JUAN FERNÁNDEZ VAlVERDE: Roderici Ximenii de Rada Historia de rebus Hispanie sive Historia gothica (CChr.CM 72), Turnhout 1987, 3-313.

Translatio brachii S. Eugenii Toletani episcopi

Translatio brachii S. Eugenii Toletani episcopi [BHL 2691b], ed. JUAN FRANCISCO RIVERA RECIO: San Eugenio de Toledo y su culto (Publicaciones del Instituto Provincial de Investigaciones y Estudios Toledanos. Serie 1: Monografías 1), Toledo 1963, 176-183 [= ed. ID.: Los textos hagiográficos más antiguos sobre San Eulogio de Toledo (Publicaciones del Instituto Provincial de Investigaciones y Estudios Toledanos. Serie 2: Vestigios del pasado 2), Toledo 1963, 62-69]. 


\section{Studies}

ALFONSO ANTón e. a. 2004

Lucha política. Condena y legitimación en la España medieval, ed. by ISABEL ALFONSO ANTóN e. a. (Cahiers de linguistique et de civilisation hispaniques médiévales. Annexes 16), Lyon 2004.

ALVAR 2010

CARLOS AlVAR: Traducciones y traductores. Materiales para una historia de la traducción en Castilla durante la edad media (Historia y literatura 2), Alcalá de Henares 2010.

D’ALVERNY 1965

MARIE-ThÉRĖSE D'AlVERNY: “La connaissance de l'Islam en Occident du IX au milieu du XII siècle”, in L'Occidente e l'Islam 1965, 2, 577-602 [repr. in D'ALVERNY 1994a, nº V] and 791803 (Discussione).

D'ALVERNY 1989

MARIE-THÉRÈSE D'AlVERNY: “Les traductions à deux interprètes, d'arabe en langue vernaculaire et de langue vernaculaire en latin”, in CONTAMINE 1989, 193-206 [repr. in D'AlverNY 1994b, n III; MICHEAU 2000, 412-430].

D’ALVERNY $1994 \mathrm{a}$

MARIE-THÉRÈSE d'AlVERny ( $\dagger$ ): La connaissance de l'Islam dans l'Occident medieval, ed. by ChARLES BuRnet (Collected Studies Series 445), Aldershot 1994.

D'ALVERNY 1994b

MARIE-THÉRÈSE d’AlvERnY ( $†$ ): La transmission des textes philosophiques et scientifiques au moyen âge, ed. by CHARLES BURNETT (Collected Studies Series 463), Aldershot 1994.

D’ALVERNY/VAJDA 1951-1952

MARIE-ThÉRÈSE d’AlveRnY/GeORge VAJDA: “Marc de Tolède, traducteur d'Ibn Tūmart”, in al-Andalus 16 (1951) 99-140 and 259-307; ibid. 17 (1952) 1-56 [repr. in D’ALvERNY 1994a, nº II].

ANGENENDT 2009

ARnold ANGENENDT: “Die Kreuzzüge. Aufruf zum ‘gerechten' oder zum ‘heiligen' Krieg?”, in HOLZEM 2009, 341-367.

ARIZALETA 2006

Amaia Arizaleta: “La 'Chronica regum Castellae'. Aledaños de la ficción”, in e-Spania. Revue électronique d'études hispaniques médiévales 2 (2006)

[http://e-spania.revues.org/517].

ARIZALETA 2008a

Amala Arizaleta: “Diffusion et reception des chroniques. 'Chronica Naiarensis', 'Liber regum', 'Chronica regum Castellae”, in ARIZALETA 2008b, 107-134.

ARIZALETA 2008b

Poétique de la chronique. L'écriture des textes historiographiques au moyen âge (Péninsule ibérique et France), ed. by Amala ARIzALeta (Méridiennes. Études médiévales ibériques), Toulouse 2008.

Arte y cultura mozárabe 1979

Arte y cultura mozárabe. Ponencias y comunicaciones presentadas al I Congreso Internacional de Estudios Mozárabes, Toledo 1975 (Instituto de Estudios Visigótico-Mozárabes de San Eugenio - Toledo. Serie A. 1), Toledo 1979.

ASÍN Y PALACIOS 1919

Miguel Asín y Palacios: La escatología musulmana en la 'Divina Comedia', Madrid 1919. 
Asín Y PALACIOS 1943

Miguel Asín y Palacios: La escatología musulmana en la 'Divina Comedia', seguida de la Historia y crítica de una polémica, Madrid/Granada ${ }^{2} 1943$.

BALLESTEROS BERETTA 1940-1941

Antonio Ballesteros Beretta: “Don Juan 'el canciller”, in Correo erudito 1 (1940-1941) 145151.

BAUER/HERBERS 2000

Hagiographie im Kontext. Wirkungsweisen und Möglichkeiten historischer Auswertung, ed. by Dieter Richard BAUER/KLAUS HeRbers (Beiträge zur Hagiographie 1), Stuttgart 2000.

BAUTISTA 2006

FRANCISCO BAUtista: "Escritura cronística e ideología histórica. La 'Chronica latina regum Castellae”, in e-Spania. Revue électronique d'études hispaniques médiévales 2 (2006) [http://e-spania.revues.org/document429.html].

BENITO VIDAL 1961

Antonio Benito Vidal: “La fecha de la ‘Crónica Seudo Isidoriana”, in Saitabi 11 (1961) 247252.

BIETENHOLZ 1994

Peter Gerard Bietenholz: Historia and fabula. Myths and legends in historical thought from antiquity to the modern age (Brill's Studies in Intellectual History 59), Leiden e. a. 1994.

BISCHOFF 1984a

BERNHARD BISCHOFF: Anecdota novissima. Texte des vierten bis sechzehnten Jahrhunderts (Quellen und Untersuchungen zur Lateinischen Philologie des Mittelalters 7), Stuttgart 1984.

BISCHOFF 1984b

BERNHARD BISCHOFF: “Ein Leben Mohammeds (Adelphus?) (Zwölftes Jahrhundert)”, in BISCHOFF 1984a, 106-122.

BLEY e. a. 2014

Discourses of purity in transcultural perspective (300-1600), ed. by MATTHIAS BLEY e. a. (Dynamics in the History of Religions 7), Leiden/Boston 2014 (in print).

BORGOLTE/TISCHLER 2012a

Michael Borgolte/Matthias Martin Tischler: “Einleitung”, in Borgolte/Tischler 2012b, 9-20.

BORGOLTE/TISCHLER 2012b

Transkulturelle Verflechtungen im mittelalterlichen Jahrtausend. Europa, Ostasien, Afrika, ed. by Michael Borgolte/MatTHias Martin TISCHLER, Darmstadt 2012.

BURKE 2000

PETER BURKE: Kultureller Austausch (Erbschaft unserer Zeit 8. edition suhrkamp 2170), Frankfurt am Main 2000 [2002].

BURSCHEL/MARX 2011

Reinheit, ed. by Peter BURSCHeL/ChrIStOPH MARX (Veröffentlichungen des Instituts für Historische Anthropologie 12), Wien e. a. 2011.

CABANES PECOURT 1964

María Desamparados Cabanes Pecourt: “[Introducción]”, in ead. (ed.): Crónica latina de los reyes de Castilla. Edición crítica e índices (Textos medievales 11), València 1964, 5-12.

CAMERON/CONRAD 1992

The Byzantine and early Islamic Near East 1: Problems in the literary source material, ed. by Averil Cameron/LaWrence Irvin ConRad (Studies in Late Antiquity and Early Islam 1), Princeton (NJ.) 1992 [repr. Princeton (NJ.) 2003]. 
CARDELLE DE HARTMANN 2001

Carmen Cardelle de Hartmann (ed.): Victoris Tunnunensis Chronicon cum reliquiis ex Consularibus Caesaraugustanis et lohannis Biclarensis Chronicon (CChr.SL 173 A), Turnhout 2001.

CARdelle de HartMann 2011

Carmen Cardelle de Hartmann: "Der mozarabische Blick auf die Geschichte. Tradition und Identitätsbildung”, in MASER/HERBERS 2011, 39-63.

DE CARLOS VILLAMARÍN 1996

Helena de Carlos Villamarín: Los antigüedades de Hispania (Biblioteca di Medioevo latino 18), Spoleto 1996.

CARRUTHERS 1990

MARY JEAN CARRUTHERS: The book of memory. A study of memory in medieval culture (Cambridge Studies in Medieval Literature 10), Cambridge e. a. 1990 [22008].

Catalán MenÉndez-PIDAL 1975

Diego Catalán [MenÉndez-PIDAL]: "Las fuentes latinas y mozárabes de al-Rāzī y el Rasis romanzado", in ID. (ed.): Crónica del moro Rasis. Versión del Ajbār mulūk al-Andalus de Aḥmad ibn Muḥammad ibn Mūsà al-Rāzī, 889-955. Romanzada para el rey Don Dionís de Portugal hacia 1300 por Mahomad, alarife, y Gil Pérez, clérigo de Don Perianes Porçel (Fuentes cronísticas de la historia de España 3), Madrid 1975, XXIX-LXIX.

Chalmeta GENDRÓN 1972

Pedro Chalmeta Gendrón: “Historiografía medieval hispana. Arabica”, in al-Andalus 37 (1972) 353-404.

Chalmeta GendRón 1973

Pedro Chalmeta [GendRón]: “Una historia discontinua e intemporal (jabar)”, in Hispania 123 (1973) 23-75.

CHARLO BREA 1995

LUIS ChARlo BREA: “¿Un segundo autor para la última parte de la 'Crónica latina de los reyes de Castilla'?", in PéreZ GonZÁlez 1995, 251-256.

CHARLO BREA 1997

LUIS ChARLo BREA: “Introducción”, in ID. (ed.): Chronica Hispana saeculi XIII (CChr.CM 73), Turnhout 1997, 9-31.

CHARLO BREA 1998

luis Charlo Brea: "El latín del obispo de Osma”, in Pérez González 1998, 1, 351-361.

Charlo BREA 2011

LUIS ChARlo BRea: “Novedades en la ‘Chronica Latina regum Castellae”, in MARTínez GÁzQuez e. a. $2011,881-889$.

CHRISTYS 2002

ANN CHRISTYS: Christians in al-Andalus (711-1000) (Culture and Civilization in the Middle East), Richmond 2002.

CHRISTYS 2006

ANN CHRISTYS: “'How can I trust you, since you are a Christian and I am a Moor?'. The multiple identities of the Chronicle of Pseudo-Isidore”, in CORRADINI e. a. 2006, 359-372.

CHRISTYS 2010

ANN CHRISTYS: “Expanding/expounding the Chronicle of Pseudo-Isidore. Paris, BN lat. 6113", in CORRADINI e. a. 2010, 79-91. 


\section{Cipollone 2000}

La liberazione dei 'captivi' tra Cristianità e Islam. Oltre la crociata e il ğihād. Tolleranza e servizio umanitario, ed. by GIULIO CIPOLlone (Collectanea Archivi Vaticani 46), Città del Vaticano 2000.

\section{CIROT 1912}

GEORGES CIROT: "Une chronique latine inédite des rois de Castille (1236)", in Bulletin hispanique 14 (1912) 30-46 and plates V-VIII.

\section{CIROT 1912-1913}

GEORGES CIROT: “Chronique latine des rois de Castille jusqu'en 1236”, in Bulletin hispanique 14 (1912) 109-118, 244-274 and 353-374; ibid. 15 (1913) 18-37, 170-187, 268-283 and 411-427.

\section{CIROT 1917-1919}

GEORGES CIROT: “Appendices à la Chronique latine des rois de Castille jusqu'en 1236", in Bulletin hispanique 19 (1917) 101-115 and 243-258; ibid. 20 (1918) 27-35 and 149-184; ibid. 21 (1919) 173-192 [with 3 figures].

CIROT 1919-1923

GEORGES CIROT: "Recherches sur la Chronique latine des rois de Castille", in Bulletin hispanique 21 (1919) 193-217 and 276-281 [with 2 figures]; ibid. 25 (1923) 97-107.

CIROT 1920

GEORGES CIROT: “Une chronique latine inédite des rois de Castille (1236)", in Bulletin hispanique 22 (1920) 1-153.

CIROT 1926-1927

GEORGES CIROT: “Anecdotes ou légendes sur l'époque d'Alphonse VIII", in Bulletin hispanique 28 (1926) 246-259; ibid. 29 (1927) 145-173, 241-254 and 337-350.

\section{CLAUde 1988}

DIETRICH CLAUDE: “Untersuchungen zum Untergang des Westgotenreiches (711-725)”, in Historisches Jahrbuch 108 (1988) 329-358.

\section{COLBERT 1962}

EdWARd P. COlBeRT: The martyrs of Córdoba (850-859). A study of the sources (The Catholic University of America. Studies in Mediaeval History N. S. 17), Washington (D.C.) 1962.

\section{COLE 1993}

PENNY J. Cole: “'O God, the heathen have come into your inheritance' (Ps 78.1). The theme of religious pollution in crusade documents, 1095-1188”, in SHATZMILLER 1993, 84-111.

\section{COLEMAN 1992}

Janet Coleman: Ancient and medieval memories. Studies in the reconstruction of the past, Cambridge e. a. 1992 [1995].

COLLINS 1989

ROGER ColuINS: The Arab conquest of Spain 710-797, Oxford/Cambridge (Ma.) 1989.

CONTAMINE 1989

Traduction et traducteurs au moyen âge. Actes du Colloque international du CNRS organisé à Paris, Institut de recherche et d'histoire des textes, les 26-28 mai 1986, ed. by GENEVIÈVE CONTAMINE, Paris 1989.

CORRADINI e. a. 2006

Texts and identities in the Early Middle Ages, ed. by RICHARD CORRADINI e. a. (Forschungen zur Geschichte des Mittelalters 12. Denkschriften der Philosophisch-Historischen Klasse der Österreichischen Akademie der Wissenschaften 344), Wien 2006. 
CORRADINI e. a. 2010

Zwischen Niederschrift und Wiederschrift. Hagiographie und Historiographie im Spannungsfeld von Kompendienüberlieferung und Editionstechnik, ed. by RICHARD CORRADINI e. a. (Forschungen zur Geschichte des Mittelalters 18. Denkschriften der Philosophisch-Historischen Klasse der Österreichischen Akademie der Wissenschaften 405), Wien 2010.

CREGO GÓMEZ 2006

MARÍA CREGo GómEZ: "La fuente árabe de la historia del Emirato omeya de al-Andalus en la 'Historia Arabum' de Jiménez de Rada”, in e-Spania. Revue électronique d'études hispaniques médiévales 2 (2006) [http://e-spania.revues.org/document274.html].

CRESSIER e. a. 2005

Los Almohades. Problemas y perspectivas 1: Edad media, historia, arqueología, epigrafía, numismática; ... 2: al-Andalus, Magreb, Época almohade, ed. by PATRICE CRESSIER e. a. (Estudios árabes e islámicos. Monografías 11), Madrid 2005.

Cristianismo e Islam 2011

Cristianismo e Islam en el siglo de las Navas de Tolosa (1212) [= Anuario de Historia de la Iglesia 20 (2011) 99-260], Pamplona 2011.

CUTLER 1965

ALLAN [HARRIS] CUTLER: “The ninth-century Spanish martyrs' movement and the origins of Western Christian missions to the Muslims", in The Muslim World 55 (1965) 321-339.

DAIBER 1986

HANS DAIBER: “Orosius' 'Historiae adversus paganos' in arabischer Überlieferung”, in VAN HENTEN e. a. 1986, 202-249.

DAIBER 2011

HANS DAIBER: "Weltgeschichte als Unheilsgeschichte. Die arabische Übersetzung von Orosius' 'Historiae adversus paganos' als Warnung an die Muslime Spaniens", in TISCHLER/ FIDORA 2011, 191-200.

DANIEL 1975

NoRman DANIEL: The Arabs and mediaeval Europe (Arab Background Series), London/New York 1975 (etc.).

DANIEL 1993

NORMAN DANIEL: Islam and the West. The making of an image, Oxford ${ }^{2} 1993$ [2000].

DESWARTE 2000

THOMAS DESWARTE: “Le viol commis par Rodrigue et la perte de l'Espagne dans la tradition mozarabe (VIII $-\mathrm{xII}$ e siècles)”, in Rouche 2000, 69-79.

DÍAZ Y DÍAZ 1970

MANUel CeCilio díAz y díAz: “La historiografía hispana desde la invasión árabe hasta el año 1000”, in La storiografia altomedievale 1970, 1, 313-343 [repr. in DíAZ Y DíAZ 1976, 203-234] and 353-355 (Discussione).

DíAZ Y DíAz 1976

MANUel CeCILIo Díaz y Díaz: De Isidoro al siglo XI. Ocho estudios sobre la vida literaria peninsular (El Albir universal 3), Barcelona 1976.

DíAz Y DíAz 1979

MANUel CECILIo díaz y DíAz: “La vida literaria entre los mozárabes de Toledo (siglos VIII-XI)”, in Arte y cultura mozárabe 1979, 71-100.

DOANE/PASTERnACK 1991

Vox intexta. Orality and textuality in the middle ages, ed. by Alger Nicolaus Doane/Carol Braun Pasternack, Madison (Wi.) 1991. 


\section{DONNER 1998}

FRED MCGRAW DONNER: Narratives of Islamic origins. The beginnings of Islamic historical writing (Studies in Late Antiquity and Early Islam 14), Princeton (NJ.) 1998 [repr. Princeton (NJ.) 1999, 2006].

DREWS 2006

WOLFRAM DREWS: “'Sarazenen' als Spanier? Muslime und kastilisch-neogotische Gemeinschaft bei Rodrigo Jiménez de Rada († 1247)”, in SPEER/WEGENER 2006, 259-281.

DREWS 2011

WolfRAm DREWS: “Transkulturelle Perspektiven in der mittelalterlichen Historiographie. Zur Diskussion welt- und globalgeschichtlicher Entwürfe in der aktuellen Geschichtswissenschaft”, in Historische Zeitschrift 292 (2011) 31-59.

ECHEVARRÍA ARSUAGA 2005

AnA EChEVARRía [ARSUAGA]: “Eschatology or biography? Alfonso X, Muhammd's ladder and a Jewish go-between", in ROBINSON/ROUHI 2005, 133-152.

Études d'orientalisme 1962

Études d'orientalisme dédiées à la mémoire de Levi-Provençal 1-2, Paris 1962.

FALQUE REY 2001

EMmA FALQUe [ReY]: “La conquista de Córdoba en las fuentes cristianas. La versión de Lucas de Túy", in Boletín de la Real Academia de Córdoba, de Ciencias, Bellas Letras y Nobles Artes 80 (2001) 177-181.

FALQUE REY 2006

Emma Falque [ReY]: "La conquista de Córdoba y la historiografía latina de la edad media", in ROdRÍGUEZ-PANTOJA 2006, 1, 545-554.

FERNÁNDEZ MARTíN 1964

Pedro Fernández Martín: "El obispo de Osma Don Juan Díaz, canciller de Fernando III el Santo, no se llamaba Don Juan Domínguez”, in Celtiberia 27 (1964) 79-95 [with 2 figures].

FERNÁNDEZ ORDÓÑEZ 2002-2003

INÉS FERNÁNDEZ ORDÓÑEZ: “De la historiografía fernandina a la alfonsi”, in Alcanate. Revista de estudios alfonsíes 3 (2002-2003) 93-133.

FERNÁNDEZ ORDÓÑEZ 2006

INÉS FERNÁNDEZ ORDÓÑEZ: “La composición por etapas de la 'Chronica latina regum Castellae' (1223-1237) de Juan de Soria”, in e-Spania. Revue électronique d'études hispaniques médiévales 2 (2006) [http://e-spania.revues.org/document283.html].

Fernando III 2003

Fernando III y su tiempo (1201-1252). VIII Congreso de Estudios Medievales, Ávila 2003.

FERRÉ 1966a

ENGRACIA FERRÉ: Rodrigo Jiménez et son 'Historia Arabum', Paris 1966.

FERRÉ 1966b

ENGRACIA FERRÉ: “Une source nouvelle pour l'histoire de l'Espagne musulmane”, in Arabica. Revue d'études arabes 13 (1966) 320-326.

FERRERO HERNÁNDEZ 2008

CÁndida FerRero HeRnández: “Cristianos y Musulmanes en la 'Historia Arabum' de Rodrigo Jiménez de Rada”, in The Journal of Medieval Latin 18 (2008) 356-373.

FEUCHTER e. a. 2011

Cultural transfers in dispute. Representations in Asia, Europe and the Arab World since the Middle Ages, ed. by JÖRg FEUCHTER e. a. (Eigene und fremde Welten 23), Frankfurt am Main/New York 2011. 


\section{FIDORA/TISCHLER 2012}

Discovering religion as a historical phenomenon. Changes in the perception of Judaism, Christianity and Islam during the Middle Ages [= Quaderns de la Mediterrània 16 (2011) 143-168 and 296-314], ed. by AleXANDER FIDORA/MATTHIAS MARTIN TISCHLER, Barcelona 2012.

\section{FLORI 1992}

JEAN FLORI: “La caricature de l'Islam dans l'Occident médiéval. Origines et signification de quelques stéréotypes concernant l'Islam", in Aevum. Rassegna di scienze storiche linguistiche et filologiche 2 (1992) 245-256.

GARCÍA DE LA BORBOLLA 2000

Ángeles García de la Borbolla: "Santo Domingo de Silos y las milagrosas redenciones de cautivos en tierras andalusíes (siglo XIII)", in CIPOLLONE 2000, 539-548.

GARCÍA DE LA BORBOLLA 2006

Ángeles GARCía de LA BORBolla: "La hagiografía de frontera. Los santos como defensores de un espacio a partir de los relatos hagiográficos peninsulares (siglos XII-XIII)", in MERISALO 2006, 675-691.

GARCíA DE CORTÁzAR 1994

Historia de España 16: La época del gótico en la cultura española (c. 1220 - c. 1480), ed. by José Ángel GarCía de CoRTÁzAR, Madrid 1994.

GAUTIER-DALCHÉ 1981

JeAN-JACQUES GAUTIER-DALCHÉ: “L'Islam, les musulmans, les rapports entre Chrétiens et Musulmans dans la littérature de l'espace Léono-Castillan (XII ${ }^{\text {ème }}$ et XIII ${ }^{\text {ème }}$ siècles)", in GENTIL DA SILVA/POLLINO 1981, 47-65.

GAUTIER-DALCHÉ 1984

PATRICK GAUtier-DAlChÉ: “Notes sur la “Chronica Pseudo-Isidoriana”, in Anuario de estudios medievales 14 (1984) 13-32.

GEARY 1994

PATRICK JOSEPH GEARY: Phantoms of remembrance. Memory and oblivion at the end of the first millenium (European history), Princeton (NJ.) 1994 [1996].

GENTIL dA SILVA/POLLINO 1981

L'histoire à Nice 2: Actes du Colloque franco-polonais d'histoire 'Les relations économiques et culturelles entre l'Occident et l'Orient', Nice - Antibes, 6-9 novembre 1980: Relations marchandes et cadre culturel du vil ${ }^{\text {Ime }}$ au xvème. Nouvelles relations et nouveaux antagonismes. L'Occident héritier de l'Orient et son agresseur. De l'antagonisme politique à l'antagonisme doctrinal, ed. by JosÉ GentIL dA SILVA/AleX Pollino, Nice 1981.

GIL FERNÁNDEZ 1973

JUAN GIL [FERNÁNDEZ]: “Praefatio”, in ID. (ed.): Corpus Scriptorum Muzarabicorum 1 (Manuales y anejos de 'Emerita’ 28, 1), Madrid 1973, XIII-LXIV.

GIL FERNÁNDEZ 1995

JUAN GIL [FERNÁNDEZ]: “La historiografía”, in LóPEZ ESTRADA 1995, 1-109 [with 31 figures].

GOETZ 1999

HANS-WERNER GOETZ: Geschichtsschreibung und Geschichtsbewußtsein im hohen Mittelalter (Orbis mediaevalis. Vorstellungswelten des Mittelalters 1), Berlin 1999 [22008].

GONZÁLEZ GONZÁLEZ 1975

Julıo GonzÁlez [GonzÁlez]: “La crónica latina de los reyes de Castilla”, in Homenaje Millares Carlo 1975, 2, 55-70. 
GONZÁLEZ JIMÉNEZ 2003

MANUEL GonzÁlez JIMÉNEZ: “Sobre la ideología de la reconquista. Realidades y tópicos”, in DE LA IGLESIA DUARTE 2003, 151-170.

GONZÁLEZ MUÑOZ 1990

Fernando GonzÁlez MuÑoz: “Una nota sobre las fuentes de la “Historia Pseudo-Isidoriana”, in Euphrosyne N. S. 18 (1990) 281-290.

GONZÁlEZ MUÑOZ 2000

FERNANDO GONZÁlEZ MUÑOZ: “Introducción”, in ID. (ed.): La chronica gothorum pseudo-isidoriana (ms. Paris BN 6113). Edición crítica, traducción y estudio (Biblioteca Filológica 6), A Coruña 2000, 11-108.

GOODY 1987

JACK GOODY: The interface between the written and the oral (Studies in Literacy, Family, Culture and the State), Cambridge e. a. 1987 (etc.).

Goody e. a. 1986

Entstehung und Folgen der Schriftkultur, ed. by JACK GOODY e. a. (Suhrkamp-Taschenbuch Wissenschaft 600), Frankfurt am Main 1986 (etc.).

GRIFFEL 2005

FRANK GRIFFEL: “Ibn Tūmart's rational proof for God's existence and unity, and his connection to the Niẓāmiyya 'madrasa' in Baghdad”, in CRESSIER e. a. 2005, 2, 753-813.

GROSS/OHLIG 2008

Schlaglichter. Die beiden ersten islamischen Jahrhunderte, ed. by MARKUS GROSS/KARLHEINZ OHLIG (Inârah. Schriften zur frühen Islamgeschichte und zum Koran 3), Berlin 2008. HÄRTEL 1995

Neue Wege zur Erschließung von Urkundenformeln, ed. by REINHARD HÄRTEL (Lectiones eruditorum extraneorum in Facultate Philosophica Universitatis Carolinae Pragensis factae 4), Praha 1995.

HARRIS 1997

JULIE ANN HARRIS: "Mosque to church. Conversions in the Spanish Reconquest", in Medieval Encounters. Jewish, Christian and Muslim Culture in Confluence and Dialogue 3 (1997) 158172.

HENRIET 2000

Patrick HenRIET: “Hagiographie et historiographie en Péninsule Iberique ( $\mathrm{XI}^{\mathrm{e}}-\mathrm{xIII}$ e siècles). Quelques remarques”, in MARTIN 2000, 53-85.

VAN HENTEN e. a. 1986

Tradition and re-interpretation in Jewish and early Christian literature. Essays in honour of Jürgen C. H. Lebram, ed. by JAN WiLlem VAN HENTEN e. a. (Studia Post-biblica 36), Leiden 1986. HERBERS/JASPERT 2007

Grenzräume und Grenzüberschreitungen im Vergleich. Der Osten und der Westen des mittelalterlichen Lateineuropa, ed. by KLAUS HERBERS/NIKOLAS JASPERT (Europa im Mittelalter. Abhandlungen und Beiträge zur historischen Komparatistik 7), Berlin 2007.

HERNÁNDEZ 2003

FRANCISCO JAVIER HeRnÁNDEZ: “La corte de Fernando III y la casa real de Francia. Documentos, crónicas y monumentos”, in Fernando III 2003, 103-155 [with 2 figures].

HIRSCHLER 2006

KONRAD HIRSCHLER: Medieval Arabic historiography. Authors as actors (SOAS/Routledge Curzon Studies on the Middle East 5) London/New York 2006. 
HOLZEM 2009

Krieg und Christentum. Religiöse Gewalttheorien in der Kriegserfahrung des Westens, ed. by ANDREAS Holzem (Krieg in der Geschichte 50), Paderborn e. a. 2009.

Homenaje Millares Carlo 1975

Homenaje a Don Agustín Millares Carlo 1-2, Las Palmas 1975.

HOTZ 2002

STEPHAN HOTZ: Mohammed und seine Lehre in der Darstellung abendländischer Autoren vom späten 11. bis zur Mitte des 12. Jahrhunderts. Aspekte, Quellen und Tendenzen in Kontinuität und Wandel (Studien zur Klassischen Philologie 137), Frankfurt am Main e. a. 2002.

HUBEL/SCHNEIDMÜLLER 2004

Aufbruch ins zweite Jahrtausend. Innovation und Kontinuität in der Mitte des Mittelalters, ed. by ACHIM Hubel/BeRnd SCHNEIDMÜLler (Mittelalter-Forschungen 16), Ostfildern 2004.

DE LA IGLESIA DUARTE 2003

Memoria, mito y realidad en la historia medieval. XIII Semana de Estudios Medievales, Nájera, del 29 de julio al 2 de agosto de 2002, ed. by JOSÉ IGNACIO DE LA IGLESIA DUARTE, Logroño 2003.

JEAN-MARIE 2005

StÉPHANIE JeAN-MARIE: “Violence et pouvoir dans la 'Chronica latina regum Castellae”, in Cahiers d'études hispaniques médiévales 28 (2005) 267-280.

JOSSERAND 2003

PHILIPPE JOSSERAND: “Les ordres militaires dans la chronique castillane à l'époque de Rodrigo Jiménez de Rada”, in Cahiers de linguistique et de civilisation hispaniques médiévales 26 (2003) 123-132.

KAMPERS 2008

GERD KAMPERS: Geschichte der Westgoten, Paderborn e. a. 2008.

KEDAR 1984

Benjamin Zeev Kedar: Crusade and mission. European approaches toward the Muslims, Princeton (NJ.) 1984.

KÖPF/BAUER 2011

Kulturkontakte und Rezeptionsvorgänge in der Theologie des 12. und 13. Jahrhunderts, ed. by ULRICH KÖPF/DIETER RICHARD BAUER (Archa Verbi. Subsidia 8), Münster in Westfalen 2011.

KRAPPE 1923

AlEXANDER HAGgeRTY KRAPPE: The legend of Rodrick last of the Visigoth kings and the Ermanarich cycle, Heidelberg 1923.

KUCHENBUCH/KLEINE 2006

'Textus' im Mittelalter. Komponenten und Situationen des Wortgebrauchs im schriftsemantischen Feld, ed. by LUdolf KUCHENBUCH/UTA KLEINE (Veröffentlichungen des Max-Planck-Instituts für Geschichte 216), Göttingen 2006.

LAMBERT/NICHOLSON 2012

Languages of love and hate. Conflict, communication, and identity in the medieval Mediterranean, ed. by Sarah Lambert/Helen Nicholson (International Medieval Research 15), Turnhout 2012.

LEDER 1992

Stefan Leder: "The literary use of the 'khabar'. A basic form of historical writing”, in CAMERON/CONRAD 1992, 277-315. 
LEVI DELLA VIDA 1943

GIORGIO LeVI DELLA VIDA: “The 'bronze era' in Moslem Spain”, in Journal of the American Oriental Society 63 (1943) 183-191.

LEVI DELLA VIDA 1951

GIORGIO LEVI DELLA VIDA: “La traduzione araba delle Storie di Orosio”, in Miscellanea Galbiati 1951, 3, 185-203 [with 2 plates] [revised repr. LEVI DELLA VIDA 1954].

LEVI DELLA VIDA 1954

GIORGIO LEVI DELLA VIDA: “La traduzione araba delle Storie di Orosio”, in al-Andalus 19 (1954) 257-293 [with plates 9 sq.].

LEVI DELLA VIDA 1962

GIORGIO LEVI DELLA VIDA: “Un texte mozarabe d'histoire universelle”, in Études d'orientalisme 1962, 1, 175-183 [repr. in LEVI DELLA VIDA 1971, 123-132].

LEVI DELLA VIDA 1971

GIORGIO LEVI DELLA VIDA (†): Note di storia letteraria arabo-ispanica, ed. by MARIA NALLINo (Pubblicazioni dell'Istituto per l'Oriente 65), Roma 1971.

LIFSHITZ 1994

FELICE LIFSHITZ: “Beyond positivism and genre. 'Hagiographical' texts as historical narrative”, in Viator 25 (1994) 95-113.

LINEHAN 1993

PETER LINEHAN: History and the historians of medieval Spain, Oxford 1993.

LINEHAN 2003a

Peter Linehan: “Don Juan de Soria. Unas apostillas”, in Fernando III 2003, 375-393 [repr. in LINEHAN 2012, $\mathrm{n}^{\circ}$ IV].

LINEHAN 2003b

PETER LINEHAn: “Don Rodrigo and the government of the kingdom”, in Cahiers de linguistique et de civilisation hispaniques médiévales 26 (2003) 87-99 [repr. in LINEHAN 2012, $\mathrm{n}^{\circ}$ III].

LINEHAN 2006

Peter LINeHAN: "Juan de Soria. The chancellor as chronicler", in e-Spania. Revue électronique d'études hispaniques médiévales 2 (2006)

[http://e-spania.revues.org/document276.html] [repr. in LINEHAN 2012, $\mathrm{n}^{\circ} \mathrm{V}$ ].

LINEHAN 2012

PETER LINEHAN: Historical memory and clerical activity in medieval Spain and Portugal (Collected Studies Series 1011), Farnham 2012.

LOMAX 1963

DeReK William LomaX: “The authorship of the 'Chronique latine des rois de Castille”, in Bulletin of Hispanic Studies 40 (1963) 205-211.

LóPEZ ESTRADA 1995

Historia de España 11: La cultura del románico. Siglos XI al XIII. Letras, religiosidad, artes, ciencia y vida, ed. by Francisco LóPEZ EstradA, Madrid 1995 [21997].

LóPEZ SANTIDRIÁN 1984

El factor religioso en la formación de Castilla, ed. by SATURnIno LóPEZ SANTIDRIÁN (Publicaciones de la Facultad de Teología del Norte de España. Sede de Burgos 50), Burgos 1984.

LUCHITSKAJA 1999

SVETLANA LUCHITSKAJA: “L'image des musulmans dans les chroniques des croisades", in Le moyen âge 105 (1999) 717-735. 
MAGNOU-NORTIER 1974

ÉlISABETH MAGNOU-NORTIER: La société laïque et l'Église dans la province ecclésiastique de Narbonne (zone cispyrénéenne) de la fin du VIII' à la fin du XI siècle (Publications de l'Université de Toulouse-Le Miral. Série A. 20), Toulouse 1974.

MANZANO MORENO 1999

EdUARDo MANZANo MOREnO: “Las fuentes árabes sobre la conquista de al-Andalus. Una nueva interpretación”, in Hispania 202 (1999) 389-432.

MARTIN 2000

Actes du Colloque 'Histoire des idées politiques dans l'Espagne médiévale. Conceptions et représentations de la royauté (XII - XIV siècles)', Paris, 21-22 novembre 1997 [= Cahiers de linguistique hispanique médiévale 23 (2000)], ed. by GEORGES MARTIN, Lyon 2000.

MARTIN 2006

GEORGES MARTIN: "La contribution de Jean d'Osma à la pensée politique castillane sous le règne de Ferdinand III", in e-Spania. Revue électronique d'études hispaniques médiévales 2 (2006) [http://e-spania.revues.org/document280.html].

Martínez GÁZquez e. a. 2011

Estudios de latín medieval hispánico. Actas del V Congreso Internacional de Latín Medieval Hispánico, Barcelona, 7-10 de septiembre de 2009 (Millennio medievale 92. Strumenti e studi N. S. 30), ed. by José Martínez Gázquez e. a., Firenze 2011.

MASER 2006

MATTHIAS MASER: Die 'Historia Arabum' des Rodrigo Jiménez de Rada. Arabische Traditionen und die Identität der Hispania im 13. Jahrhundert. Studie - Übersetzung - Kommentar (Geschichte und Kultur der Iberischen Welt 3), Berlin 2006.

MASER 2007

MATTHIAS MASER: “Übersetzung und Identität. Überlegungen zu Intentionen und Kontexten des Iberischen Übersetzungswerkes im Mittelalter”, in HERBERS/JASPERT 2007, 241-260.

MASER 2012

MATTHIAS MASER: “Rodrigo Jiménez de Rada and his 'Historia Arabum'. An extraordinary example of inter-cultural tolerance?”, in LAMBERT/NICHOLSON 2012, 223-238.

MASER/HERBERS 2011

Die Mozaraber. Definitionen und Perspektiven der Forschung, ed. by MATTHIAS MASER/ KLAUS HERBERS (Geschichte und Kultur der Iberischen Halbinsel 7), Berlin 2011.

MENÉNDEZ PIDAL 1924

RAMÓN MENÉNDEZ PIDAL: El rey Rodrigo en la literatura, Madrid 1924.

MENÉNDEZ PIDAL 1951

Gonzalo Menéndez Pidal: “Cómo trabajaron las escuelas alfonsíes”, in Nueva revista de filología hispanica 5 (1951) 363-380.

MENÉNDEZ PIDAL 1954

RAMÓn MenÉndez PIDAL: "Sobre la Crónica Pseudo Isidoriana, obra de un mozárabe arabizado", in Cuadernos de historia de España 21-22 (1954) 5-15 [repr. in MENÉNDEZ PIDAL 2001, 139-147].

MENÉNDEZ PIDAL 2001

RAMON MENÉNDEZ PIDAL (†): Islam y cristiandad. España entre las dos culturas, ed. by ÁlVARO GALmÉs de Fuentes (Analecta Malacitana. Anejo 33 de la Revista de la Sección de Filología de la Facultad de Filosofía y Letras), Málaga 2001. 


\section{MERISALO 2006}

Frontiers in the Middle Ages. Proceedings of the Third European Congress of Medieval Studies, Jyväskylä, 10-14 june 2003, ed. by OUTI MERISALO (Fédération Internationale des Instituts d’Études Médiévales. Textes et Études du Moyen Âge 35), Louvain-la-Neuve 2006.

MICHEAU 2000

Les relations des pays d'Islam avec le monde latin du milieu du $x^{e}$ siècle au milieu du XIII siècle, ed. by FrançoISE MICHEAU (Recherches sur ...), Paris 2000.

Miscellanea Galbiati 1951

Miscellanea Giovanni Galbiati 1: Archeologia storia, filologia e antichità classica, papirologia glottologia, arte (Fontes Ambrosiani 25), Milano 1951; ... 2: Filologia classica storia, letteratura medioevale latina e bizantina, paleografia letteratura italiana, arte (Fontes Ambrosiani 26), Milano 1951; ... 3: Archeologia, storia, filologia classica e bizantina, filologia orientale glottologia (Fontes Ambrosiani 27), Milano 1951.

MitRE FERNÁNDEZ 1994

EMILIO MITRE FERNÁNDEZ: “¿Un sentimiento de comunidad hispánica? La historiografía peninsular”, in GARCíA DE CORTÁZAR 1994, 407-434 [with 5 figures].

MOLINA MARTÍNEZ 1989

LUIS Molina [MARTínez]: “Los 'Ajbār Maŷmū'a' y la historiografía árabe sobre el período omeya en al-Andalus”, in al-Qanțara 10 (1989) 513-542.

MoLINA MARTíNEZ 1998

LUIS Molina [MARTínez]: "Un relato de la conquista de al-Andalus”, in al-Qanțara 19 (1998) 39-65.

\section{MOMMSEN 1894}

THEOdoR MOMmSEN (ed.): Chronica minora saec. IV. V. VI. VII 2 (MGH Auctores antiquissimi 11), Berlin 1894.

Montenegro Valentín/del CAStillo 2004

julia Montenegro [Valentín]/Arcadio del Castillo (rec.): “CARdelle de hartmann 2001”, in Revue belge de philologie et d'histoire 82 (2004) 1059-1063.

MUNRO 1931

Dana Carleton Munro: "The Western attitude toward Islam during the period of the crusades", in Speculum 6 (1931) 329-343.

NOTH 1993

AlBRECHT Noth: "Muhammed 3: The Prophet's image in Europe and the West. A: The image in the Latin Middle Ages", in The Encyclopaedia of Islam 7: Mif-Naz, Leiden/New York 1993, 377-381.

NOTH/CONRAD 1994

Albrecht Noth/LAWRENCE IRVIn CONRAD: The early Arabic historical tradition. A source-critical study (Studies in Late Antiquity and Early Islam 3), Princeton (NJ.) 1994 [21997].

O'CaLlaghan 2002

Joseph Francis O'Callaghan (trad.): The Latin Chronicle of the Kings of Castile. Translated with an introduction and notes (Medieval and Renaissance Texts and Studies 236), Tempe (Ariz.) 2002.

L'Occidente e l'Islam 1965

L'Occidente e l'Islam nell'alto medioevo 1-2 (Settimane di Studio del Centro Italiano di Studi sull'Alto Medioevo 12, 1-2), Spoleto 1965. 


\section{OESTERREICHER 1993}

WULF OESTERREICHER: “'Verschriftung' und 'Verschriftlichung' im Kontext medialer und konzeptioneller Schriftlichkeit”, in SCHAEFER 1993, 267-292.

OLIVER PÉREZ 2000-2001

Dolores Oliver Pérez: “Los autores del ‘Ajbār Maŷmū'a'. ¿Los Tammām b. 'Alqama?”, in Anaquel de estudios árabes 11-12 (2000-2001) 513-554.

Oliver PÉrez 2001

Dolores Oliver [PÉREz]: “El Ajbār Maŷmū'a. Una obra polémica”, in Qurțuba. Estudios andalusíes 6 (2001) 77-108.

OLIVER PÉREZ 2002

DOLORES OLIVER PÉrEZ: “De vuelta sobre el Ajbār Maŷmū'a. La historia de la invasión y de los valíes”, in Anaquel de estudios árabes 13 (2002) 131-150.

Oriente e Occidente nel medioevo 1971

Oriente e Occidente nel medioevo. Filosofia e scienze (Accademia Nazionale dei Lincei. Fondazione Alessandro Volta. Atti dei Convegni 13), Roma 1971.

Pascual Martínez 1972

Lope Pascual Martínez: “Un cronista Murciano del siglo XI. El autor de la 'Crónica Seudo Isidoriana”, in Murgetana 38 (1972) 49-60.

PATSCHOVSKY/ZIMMERMANN 1998

Toleranz im Mittelalter, ed. by AleXANDER PATSCHOVSKy/HARALd ZIMMERMAnN (Vorträge und Forschungen 45), Sigmaringen 1998.

PeNeLAS 2001a

MAYTE Penelas: “Estudio“, in EAD. (ed.): Kitāb Hurūšiyūšs. Traducción árabe de las 'Historiae adversus paganos’ de Orosio (Fuentes arábico-hispanas 26), Madrid 2001, 15-124.

PENELAS 2001b

MAYTE PENELAS: “El historiador árabe ante las fuentes cristianas. Las 'Historias de Orosio”, in PÉrez Jiménez/CRUZ ANdReottI 2001, 179-200.

Penelas 2001C

Mayte Penelas: "A possible author of the Arabic translation of Orosius' 'Historiae”, in alMasāq 13 (2001) 113-135.

Penelas 2002

MAYTE Penelas: “Del latín al árabe. Una traducción 'mozarabe' del siglo IX/X”, in PÉrez GonZÁLEZ 2002, 1, 423-432.

Penelas 2009

MAYTE Penelas: “¿Hubo dos traducciones árabes independientes de las ‘Historias contra los paganos' de Orosio?”, in Collectanea Christiana Orientalia 6 (2009) 223-251.

PéreZ GONZÁLEZ 1995

Actas del I Congreso Nacional de Latín Medieval, León, 1-4 de diciembre de 1993, ed. by MAURILIO PÉREZ GONZÁLEZ, León 1995.

PÉREZ GONZÁLEZ 1998

Actas del Il Congreso Hispánico de Latín Medieval, León, 11-14 de noviembre de 19971-2, ed. by MAURILIO PÉrEZ GonzÁLEZ, León 1998.

PÉREZ GONZÁLEZ 2002

Actas del III Congreso Hispánico de Latín Medieval, León, 26-29 de septiembre de 2002 12, ed. by MAURILIO PÉREZ GonZÁlez, León 2002. 
Pérez JIMÉnez/CRUZ ANDREOTtI 2001

La verdad tamizada. Cronistas, reporteros e historiadores ante su público, ed. by Aurelo PÉREZ JimÉnez/GonZalo CRUZ ANDREotti (Mediterránea 8), Madrid 2001.

PICK 2004

LUCY KRISTINA PICK: Conflict and coexistence. Archbishop Rodrigo and the Muslims and Jews of medieval Spain (History, Languages, and Cultures of the Spanish and Portuguese Worlds), Ann Arbor (Mi.) 2004.

PICK 2005

LUCY KRISTINA PICK: “Peter the Venerable and the new world order”, in Early Medieval Europe 13 (2005) 405-411.

PICK 2011

LUCY KRISTINA PICK: “What did Rodrigo Jiménez de Rada know about Islam?”, in Cristianismo e Islam 2011, 221-235.

REILLY 2010

Bernard Francis Reilly: “The 'Chronica Latina Regum Castellae'. Historical composition at the court of Fernando III of Castile, 1217-1252", in Viator 41 (2010) 141-154.

REINHARDT/SANTIAGO OTERO 1986

KLAUS Reinhardt/Horacio Santiago Otero: Biblioteca bíblica ibérica medieval (Medievalia et Humanistica 1. Nomenclátor de Autores Medievales Hispanos 1), Madrid 1986.

RICHARD 1971

BERNARD RICHARD: “L'Islam et les musulmans chez les chroniqueurs castillans du milieu du moyen âge”, in Hespéris Tamuda 12 (1971) 107-132.

RICHTER 1994a

MICHAEL RICHTER: The formation of the medieval West. Studies in the oral culture of the barbarians, Dublin 1994 [New York 1994].

RICHTER 1994b

MICHAEL RICHTER: The oral tradition in the Early Middle Ages (Typologie des sources du moyen âge occidental 71), Turnhout 1994.

RICHTER 1995

MICHAEL RICHTER: „Die mündliche Kultur im frühen Mittelalter - ein Problemaufriß“, in HÄRTEL 1995, 81-94.

RIVERA RECIO 1951

JuAn Francisco Rivera [ReCIO]: "Personajes hispanos asistentes en 1215 al IV Concilio de Letrán (Revisión y aportación nueva de documentos. Datos biográficos)”, in Hispania sacra 4 (1951) 335-355.

ROBINSON 2003

CHASE FREDERICK RoBINSON: Islamic historiography (Themes in Islamic History 1), Cambridge 2003 (etc.).

ROBINSON/ROUHI 2005

Under the influence. Questioning the comparative in medieval Castile, ed. by CYNTHIA ROBINSON/LEYLA ROUHI (The Medieval and Early Modern Iberian World 22), Leiden/Boston 2005.

RODRÍGUEZ LÓPEZ 2003

ANA RodríGUez [LóPEZ]: “'De rebus Hispaniae’ frente a la 'Crónica latina de los reyes de Castilla'. Virtudes regias y reciprocidad política en Castilla y León en la primera mitad del siglo XIII", in Cahiers de linguistique et de civilisation hispaniques médiévales 26 (2003) 133149. 
RODRÍGUEZ LóPEZ 2004a

ANA RODRÍGUEZ [LÓPEZ]: “History and topography for the legitimisation of royalty in three Castilian chronicles”, in Majestas 12 (2004) 61-81.

RODRÍGUEZ LÓPEZ 2004b

ANA RodRíGUEZ LóPEZ: "Légitimation royale et discours sur la croisade en Castille aux XII et XIII' siècles”, in Journal des savants 2004, 129-163.

RODRÍGUEZ LóPEZ $2004 \mathrm{C}$

ANA RODRÍGUEZ LóPEZ: "Sucesión regia y legitimidad política en Castilla en los siglos XII y XIII. Algunas consideraciones sobre el relato de las crónicas latinas castellano-leonesas", in ALFONSO ANTón e. a. 2004, 21-41.

RODRÍGUEZ LóPEZ 2006

ANA RodríGUez [LóPEZ]: “Modelos de legitimidad política en la 'Chronica regum Castellae' de Juan de Osma”, in e-Spania. Revue électronique d'études hispaniques médiévales 2 (2006) [http://e-spania.revues.org/document433.html].

ROdRígueZ-PANTOJA 2006

Las raíces clásicas de Andalucía. Actas del IV Congreso Andaluz de Estudios Clásicos 1-2, ed. by Miguel Rodríguez-PAntoja (Colección Mayor), Córdoba 2006.

ROMANO 1971

DAVID Romano: “Le opere scientifiche di Alfonso X e l'intervento degli ebrei", in Oriente $e$ Occidente nel medioevo 1971, 677-711 and 726-729 (Discussione).

ROSENTHAL 1968

FRANZ ROSENTHAL: A history of Muslim historiography, Leiden ${ }^{2} 1968$ [Leiden 1952].

ROTTER 1994

EKKEHART ROTTER: “Embricho von Mainz und das Mohammed-Bild seiner Zeit”, in STAAB 1994, 69-122.

ROTTER 2004

EKKEHART ROTTER: "Mohammed in Bamberg. Die Wahrnehmung der muslimischen Welt im deutschen Reich des 11. Jahrhunderts”, in HUBEL/SCHNEIDMÜLLER 2004, 283-344.

ROUCHE 2000

Mariage et sexualité au moyen âge. Accord ou crise? Colloque international de Conques, ed. by Michel ROUCHE (Cultures et civilisations médíevales 21), Paris 2000.

SAHNER 2013

CHRISTIAN CASEY SAHNER: "From Augustine to Islam. Translation and history in the Arabic Orosius”, in Speculum 88 (2013) 905-931.

SÁNCHEZ ALBORNOZ 1934

Claudio SÁnchez Albornoz: "La crónica del moro Rasis y la 'Continuatio Hispana”, in Anales de la Universidad de Madrid. Letras 3 (1934) 229-265 [repr. in SÁNCHEZ AlBORNOZ 1967, 267302].

SÁNCHEZ ALBORNOZ 1942a

CLAUDIO SÁNCHEZ ALBORnOZ Y MENDUIÑ: En torno a los orígenes del feudalismo 2: Los árabes y el régimen prefeudal carolingio. Fuentes de la historia hispano-musulmana del siglo VIII 2, Mendoza 1942 [repr. (Textos redivivos, libros perdurables 12), Madrid 1993; Buenos Aires $\left.{ }^{2} 1974\right]$.

SÁNCHEZ ALBORNOZ 1942b

Claudio SÁnchez Albornoz: Fuentes latinas de la Historia Romana de Rasis (Publicaciones del Instituto cultural argentino hispano-árabe 1), Buenos Aires 1942 [repr. in SÁNCHEZ ALBORNOZ 1967, 303-336]. 
SÁNCHEZ ALBORNOZ 1944

Claudio SÁnchez Albornoz: El 'Ajbār maŷmū'a'. Cuestiones historiográficas que suscita, Buenos Aires 1944.

SÁNCHEZ ALBORNOZ 1946

Claudio SÁnchez Albornoz: “San Isidoro, 'Rasis' y la ‘Pseudo Isidoriana”, in Cuadernos de historia de España 4 (1946) 73-113 [repr. in SÁnCHEZ ALBORNOZ 1967, 337-375].

SÁNCHEZ ALBORNOZ 1967

ClaUdio SÁNChez AlboRnOZ: Investigaciones sobre historiografía hispana medieval (siglos VIII al XII), Buenos Aires 1967.

SCHAEFER 1993

Schriftlichkeit im frühen Mittelalter, ed. by URSULA SCHAEFER (ScriptOralia 53), Tübingen 1993.

SCHWINGES 1998

RAINER CHRISTOPH SCHWIngES: "Die Wahrnehmung des Anderen durch Geschichtsschreibung. Muslime und Christen im Spiegel der Werke Wilhelms von Tyrus († 1186) und Rodrigo Ximénez’ de Rada († 1247)", in PATSChovsky/ZIMMERMANn 1998, 101-127.

SERRANO 1941

LUCIANO SERRANO: “El canciller de Fernando III de Castilla”, in Hispania 1 (1941) 3-40.

SERRANO Y SANZ 1931-1932

Manuel SerRano y Sanz: "Vida de Mahoma, según un códice latino de mediados del siglo XIII”, in Erudición ibero-ultramarina 2 (1931) 365-395; ibid. 3 (1932) 115-120.

SHATZMILLER 1993

Crusaders and Muslims in $12^{\text {th }}$ c. Syria, ed. by MAYA SHATZMiLleR (The Medieval Mediterranean 1), Leiden e. a. 1993.

SOUTHERN 1962

RICHARD WILLIAM SOUTHERN: Western views of Islam in the Middle Ages, Cambridge (Ma.) 1962 [Oxford ${ }^{2} 1978$ ].

SPEER/STEINKRÜGER 2006

Knotenpunkt Byzanz. Wissensformen und kulturelle Wechselbeziehungen, ed. by ANDREAS SPEER/PHILIPP STEINKRÜGER (Miscellanea Mediaevalia 36), Berlin/Boston 2012.

SPEER/WEGENER 2006

Wissen über Grenzen. Arabisches Wissen und lateinisches Mittelalter, ed. by ANDREAS SPEER/LYDIA Wegener (Miscellanea Mediaevalia 33), Berlin/New York 2006.

SPONSLER 2002

CLAIRE SPONSLER: “In transit. Theorizing cultural appropriation in medieval Europe”, in Journal of Medieval and Early Modern Studies 32 (2002) 17-39.

STAAB 1994

Auslandsbeziehungen unter den salischen Kaisern. Geistige Auseinandersetzung und Politik. Referate und Aussprachen der Arbeitstagung vom 22.-24. November 1990 in Speyer, ed. by FRANZ STAAB (Veröffentlichung der Pfälzischen Gesellschaft zur Förderung der Wissenschaften in Speyer 86), Speyer 1994.

Sтоск 1983

BRIAN STOCK: The implications of literacy. Written language and models of interpretation in the eleventh and twelfth centuries, Princeton (NJ.) 1983.

La storiografia altomedievale 1970

La storiografia altomedievale 1-2 (Settimane di Studio del Centro Italiano di Studi sull'Alto Medioevo 17, 1-2), Spoleto 1970. 
TANGL 1922

GEORGINE TANGL: Die Teilnehmer an den allgemeinen Konzilien des Mittelalters, Weimar 1922 [repr. Darmstadt 1969].

THOMAS 2008

JOHANNES THOMAS: “Frühe spanische Zeugnisse zum Islam. Vorschläge für eine differenzierte Betrachtung der Konflikte und der religiösen Gemeinsamkeiten zwischen dem Osten und dem Westen des arabischen Reiches", in Gross/OHLIG 2008, 93-186.

TISCHLER 2001

MATTHIAS MARTIN TISCHLER: Einharts 'Vita Karoli'. Studien zur Entstehung, Überlieferung und Rezeption 1-2 (MGH Schriften 48, I-II), Hannover 2001.

TISCHLER 2008

MATTHIAS MARTIN TISChLER: “Orte des Unheiligen. Versuch einer Topographie der dominikanischen Mohammed-Biographik des 13. Jahrhunderts zwischen Textüberlieferung und Missionspraxis", in Archa Verbi 5 (2008) 32-63.

TISCHLER 2009

MatThIAS MARTIN TISCHLER: “Grenzen und Grenzüberschreitung in der christlich-muslimischen Begegnung. Bemerkungen zum Stellenwert der Arabischkenntnisse in der abendländischen Missionsgeschichte", in Zeitschrift für Missionswissenschaft und Religionswissenschaft 93 (2009) 58-75.

TISCHLER 2011a

MATTHIAS MARTIN TISCHLER: "Die Iberische Halbinsel als christlich-muslimischer Begegnungsraum im Spiegel von Transfer- und Transformationsprozessen des 12.-15. Jahrhunderts”, in Cristianismo e Islam 2011, 117-155.

TISCHLER 2011b

MATTHIAS MARTIN TISCHLER: "Transfer- und Transformationsprozesse im abendländischen Islambild zwischen dem 11. und 13. Jahrhundert”, in KÖPF/BAUER 2011, 329-379.

TISCHLER 2012a

MATTHIAS MARTIN TISCHLER: “El descubrimiento del islam como fenómeno histórico. El caso de la historiografía latina de la península Ibérica entre los siglos VIII y XIII", in FIDORA/TISCHLER 2012, 302-309 [English version: TISCHLER 2012b].

TISCHLER 2012b

MATTHIAS MARTIN TISCHLER: "Discovering Islam as a historical phenomenon. The case of the Latin historiography of the Iberian Peninsula, $8^{\text {th }}$ to $13^{\text {th }}$ century", in FIDORA/TISCHLER 2012, 153-161.

TISCHLER 2012C

MATTHIAS MARTIN TISCHLER: “Eine fast vergessene Gedächtnisspur. Der byzantinisch-lateinische Wissenstransfer zum Islam (8.-13. Jahrhundert)", in SPEER/STEINKRÜGER 2012, 167-195.

TISCHLER 2013

MATTHIAS MARTIN TISCHLER: "Lost in translation. Orality as a tricky filter of memory in AraboLatin processes of transfer”, in Medievalia. Revista d'Estudis Medievals 16 (2013) 149-158. TISCHLER/FIDORA 2011

Christlicher Norden - Muslimischer Süden. Ansprüche und Wirklichkeiten von Christen, Juden und Muslimen auf der Iberischen Halbinsel im Hoch- und Spätmittelalter, ed. by Matthias Martin TISCHLer/AleXander Fidora (Erudiri Sapientia. Studien zum Mittelalter und zu seiner Rezeptionsgeschichte 7), Münster in Westfalen 2011. 
TOLAN 2003

JOHN VICTOR TOLAN: Les Sarrasins. L'Islam dans l'imagination européenne au moyen âge (Collection historique), Paris 2003 [(Flammarion poche), Paris 2006].

TOLAN/JOSSERAND 2000

Les relations des pays d'Islam avec le monde latin du milieu du $x^{e}$ au milieu du XIII siècle, ed. by John VICTOR TOLAn/PhiLIPPE JOSSERAND (Histoire médiévale. Comprendre, rechercher, s'entraîner), Paris 2000.

VIÑAYO GONZÁLEZ 1984

ANTONIO VIÑAYO [GoNZÁLEZ]: “El ideal religioso en los tres primeros siglos de la Reconquista”, in LóPEZ SANTIDRIÁN 1984, 57-85.

VOLLRATH 1991

HANNA VollRATH: "Oral modes of perception in eleventh-century chronicles", in DoANE/PASTERNACK 1991, 102-111.

WeNZEL 1995

HORST WENZEL: Hören und Sehen, Schrift und Bild. Kultur und Gedächtnis im Mittelalter, München 1995.

YATES 1966

FRANCES AMELIA YATES: The art of memory, London 1966 [repr. London 1972].

ZUMTHOR 1987

PAUl Zumthor: La lettre et la voix. De la ‘littérature’ médiévale (Poétique), Paris 1987.

* Marie Curie Senior Fellow-Research Project 'Muhammad in Latin Christian Contexts. Comparing Modes of Dis/integration of Religious Otherness in Historiographical Traditions, $8^{\text {th }}$ to $13^{\text {th }}$ Centuries' within the framework of the ERC/M4HUMAN-Programme of the Gerda Henkel-Stiftung, Düsseldorf. - This paper has been first presented as the inaugural lecture of the Workshop ' $12^{\text {th }}$ - and $13^{\text {th }}$-Century Attempts to Translate Muslim and Jewish Texts into Latin' at the RuhrUniversität Bochum, March 19, 2013. The specific aspects of orality treated in this paper have been furthermore presented under the title 'Las Crónicas árabo-latinas de la Península Ibérica y el problema de sus fuentes orales. Siglos XII y XIII' in a seminar of the línea de investigación 'Oriente en Occidente' in the Centro de Ciencias Humanas y Sociales (CCHS - CSIC), Madrid, May 16, 2013. 